\title{
A modelling study of photochemical regimes over Europe: robustness and variability
}

\author{
M. Beekmann ${ }^{1}$ and R. Vautard $^{2}$ \\ ${ }^{1}$ Laboratoire Inter-universitaire des Systèmes Atmosphériques, LISA/IPSL, Université Paris Est et 7, \\ CNRS/INSU UMR 7583, Créteil, France \\ ${ }^{2}$ Laboratoire de Sciences du Climat et de l'Environnement, CEA/CNRS/UVSQ, Gif/Yvette, France
}

Received: 11 August 2008 - Published in Atmos. Chem. Phys. Discuss.: 16 January 2009

Revised: 27 September 2010 - Accepted: 3 October 2010 - Published: 26 October 2010

\begin{abstract}
The variability of the relative sensitivity of photochemical ozone formation to volatile organic compounds (VOC) and $\mathrm{NO}_{\mathrm{x}}$ emissions, the chemical regime, over Europe during summers 2001 to 2003 is simulated with a regional scale transport-chemistry model. The robustness and variability of chemical regimes is shown. A VOC sensitive regime over North-Western Europe and a mainly $\mathrm{NO}_{\mathrm{x}}$ sensitive regime over the Mediterranean basin and Eastern Europe are found, confirming earlier published results. The chemical regime time variability, its robustness with respect to several environmental factors (seasonality, interannual variability) and with respect to model uncertainty are thoroughly analysed. For the regions with well pronounced chemical regimes over North-Western Europe and the Mediterranean, the chemical regime occurrence only slightly depends on the ozone target considered - daily ozone or $\mathrm{O}_{\mathrm{x}}\left(=\mathrm{O}_{3}+\mathrm{NO}_{2}\right)$ maximum or mean, AOT's, SOMO35, .... For these regions, differences between particular years and summer months are weak, day to day variability is significant but does not change the occurrence of one or another chemical regime. On the contrary, over North-Eastern Germany, the chemical regime changes form one day to another and is also dependent on the ozone target chosen. Expected decreases in anthropogenic $\mathrm{NO}_{\mathrm{x}}$ emissions over Europe since the last and for the next few decades have shifted and will shift chemical regimes to more $\mathrm{NO}_{\mathrm{x}}$ sensitive. The predictive skill of chemical regime indicator species is made evident at continental scale, extending their spatial range of applicability with respect to earlier studies. Several sensitivity tests were performed in order to account for major sources of model uncertainty. With the
\end{abstract}

Correspondence to: M. Beekmann (matthias.beekmann@lisa.u-pec.fr) exception of regions near ship tracks over the Mediterranean basin, the spatial pattern of chemical regimes appears to be robust with respect to model uncertainty for all cases tested.

\section{Introduction}

The relation between pollutant emissions and concentrations of gases and aerosols affecting health and ecosystems is nonlinear. That is why the management of air quality requires adequate emission control strategies. Photo-oxidant pollution, due to ozone and related trace gases, has a complex sensitivity to primary precursor emission families. The exact knowledge of this sensitivity is necessary for the management of this type of atmospheric pollution. A particular attention has been given to the question whether either nitrogen oxides $\left(\mathrm{NO}_{\mathrm{x}}\right)$ or volatile organic carbon species (VOC) emission reductions are more suitable to limit ozone pollution (e.g. Sillman et al., 1999; Milford 1994). Chemical regimes have been defined relating ozone concentrations to upwind precursor emissions: in the " $\mathrm{NO}_{\mathrm{x}}$ sensitive chemical regime", $\mathrm{NO}_{\mathrm{x}}$ anthropogenic emission reductions are more efficient to reduce ozone levels than VOC anthropogenic emission reductions (Sillman et al., 1995), and the reverse occurs in the "VOC sensitive chemical regime". Alternatively, Kleinman et al. (1997) defined chemical regimes in terms of sensitivity of local photochemical ozone production $\left(\mathrm{PO}_{3}\right)$ with respect to $\mathrm{NO}_{\mathrm{x}}$ and VOC concentrations (instead of emissions). They showed theoretically that a locally VOC sensitive chemical regime is related to a dominant odd hydrogen $\left(\mathrm{HO}_{\mathrm{x}}\right)$ radical loss through reactions between $\mathrm{NO}_{\mathrm{x}}$ and $\mathrm{HO}_{\mathrm{x}}$ species, whereas a $\mathrm{NO}_{\mathrm{x}}$ sensitive chemical regime is related to dominant loss through $\mathrm{HO}_{\mathrm{x}}$ recombination reactions.

Published by Copernicus Publications on behalf of the European Geosciences Union. 
This framework allows explaining the spatial and temporal variability of photochemical regimes with respect to environmental conditions: Large $\mathrm{NO}_{\mathrm{x}}$ emissions and concentrations favour a VOC sensitive chemical regime, large VOC emissions and concentrations, and large $\mathrm{HO}_{\mathrm{x}}$ production rates favour a $\mathrm{NO}_{\mathrm{x}}$ sensitive chemical regime. For a given $\mathrm{VOC} / \mathrm{NO}_{\mathrm{x}}$ concentration ratio, larger concentrations favour a VOC sensitive chemical regime.

Many modelling-based or observation-based studies have addressed the spatial and temporal variability of chemical regimes at urban locations and on regional scale. Using models the chemical regimes can be determined using twin simulation experiments (i.e. comparing simulations with reduced VOC and reduced $\mathrm{NO}_{\mathrm{x}}$ emissions), while from observations trace gas ratios indicating the nature of the chemical regime are used (e.g., Sillman, 1995).

Due to large emissions and low $\mathrm{VOC} / \mathrm{NO}_{\mathrm{x}}$ concentration ratios (as compared to rural background), chemical regimes during ozone pollution episodes have been shown to be generally VOC sensitive for large urban agglomerations: this has been made evident for large North American agglomerations (Los Angeles - Sillman et al., 1997; New York, Philadelphia, Phoenix - Kleinman et al., 2005; Mexico City - Lei et al., 2007), for North-Eastern Asian Megacities during spring (Beijing, Seoul, Tokyo - Guttikunda et al., 2005) and for many European agglomerations as Milano (Spirig et al., 2002; Martilli et al., 2002; Gabusi et al., 2005), Athens (Bossioli et al., 2007), Berlin (Hammer et al., 2002) and Paris (Beekmann et al., 2003; Deguillaume et al., 2008). However, for many of these cases, transitions to $\mathrm{NO}_{\mathrm{x}}$ sensitive chemical regimes occur in the plume of these agglomerations at variable distances. $\mathrm{NO}_{\mathrm{x}}$ sensitive or neutral (near transition $\mathrm{NO}_{\mathrm{x}}$-VOC sensitivity) chemical regimes can also occur within agglomerations with enhanced $\mathrm{VOC} / \mathrm{NO}_{\mathrm{x}}$ ratios due to large biogenic (Atlanta - Sillman et al., 1995; Nashville - Kleinman et al., 2005) or anthropogenic VOC sources for example due to refineries (Houston - Kleinman et al., 2005; Fos-Berre sector in southern France - Coll et al., 2005; and Paris in some circumstances - Sillman et al., 2003). To some extent, simulated chemical regimes can also depend on the model resolution as shown for several European agglomerations (Thunis et al., 2007). For simulations with an urban scale resolution $(5 \mathrm{~km})$, the VOC sensitive chemical regime for Milano and Prague is more pronounced than for models with a regional scale resolution $(50 \mathrm{~km})$, but differences were also large between different models of same resolution. .

Contrary to urban areas, rural areas are generally $\mathrm{NO}_{\mathrm{x}}$ sensitive during summer. This conclusion was obtained from simulations for US using several chemistry-transport models (Liang et al., 1998; Pierce et al., 1998), the latter study pointing to the large influence of biogenic VOC emissions to maintain the $\mathrm{NO}_{\mathrm{x}}$ sensitive regime even over more polluted areas of north-eastern US. Simulations with the EMEP unified Eulerian model show a $\mathrm{NO}_{\mathrm{x}}$ sensitive regime over the Mediterranean region, but a VOC sensitive regime over polluted parts of North-Western Europe (Tarrason et al., 2003), the latter being confirmed by a study of Derwent et al. (2003). Over Germany, results are ambiguous: a $\mathrm{NO}_{\mathrm{x}}$ sensitive chemical regime has been simulated with the EMEP unified eulerian model for summer 2000 with respect to accumulated ozone over the $60 \mathrm{ppb}$ threshold (AOT60). On the contrary, a VOC sensitive regime has been simulated with the lagrangian EMEP trajectory model for 1990 emissions with respect to AOT60 (Simpson et al., 1997). A chemical regime tracer method based on tropospheric $\mathrm{HCHO}$ to $\mathrm{NO}_{2}$ columns indicates a VOC sensitive regime over parts of Western Germany and a $\mathrm{NO}_{\mathrm{x}}$ sensitive regime elsewhere (Martin et al., 2004).

From the previous overview, it appears that uncertainties in chemical regime calculations over Europe are still large, and that a comprehensive study addressing both its spatial and temporal variability is still missing. Thus, in this work, we propose a systematic study of chemical regimes over Europe using a state of the art continental scale chemistrytransport model (CHIMERE). In addition to previous studies, we first evaluate how robust the simulated chemical regimes are with respect to the ozone target chosen, with respect to the time period of the simulation (year, month, day), and with respect to model uncertainties. Second, we also link chemical regimes variability to simulated trace gas ratios, which can be used as explanatory tool to assess the influence of emissions or meteorology on the regimes. The study aims at making evident regional scale features which are still resolved in a continental scale simulation with a $0.5^{\circ}$ horizontal resolution. Thus finer scale urban features can not be addressed in this study.

The paper is organised as follows. In Sect. 2, the set-up of the chemistry-transport model is described; the study design is explained. Results are given in Sect. 3 presenting first the spatial structure of the time averaged chemical regime and its dependency on the ozone target (Sect. 3.1) and its relation to chemical regime tracer species (Sect. 3.2). Its time variability on decadal to daily scales is analysed in Sects. 3.3 and 3.4. The robustness of the chemical regimes with respect to model uncertainty is discussed in Sect. 4. Conclusions are given in Sect. 5 .

\section{Methods}

\subsection{CHIMERE chemistry-transport model}

The model used in this study is the eulerian regional chemistry-transport model named CHIMERE (Schmidt et al., 2001) (see http://www.lmd.polytechnique.fr/chimere/). The model has been applied to simulate and analyse pollution episodes at regional (Vautard et al., 2005; Hodzic et al., 2006) and urban scale (Vautard et al., 2003; Coll et al., 2005), to analyse the sensitivity to anthropogenic (Menut et al., 2003) and biogenic emissions (Derognat et al., 2003; 
Curci et al., 2009) for long-term ozone trends analysis (Vautard et al., 2006), and for diagnostics or inverse modelling of emissions (Vautard et al., 2003; Deguillaume et al., 2007; Konovalov et al., 2006, 2008; Pison et al., 2007). The model has also been used for several years for operational forecast of pollutant levels over Western Europe (Honoré et al., 2008; http://www.prevair.org).

In this study model version V200501 was used with the following set-up: a $0.5^{\circ} \times 0.5^{\circ}$ horizontal grid covering all Europe $\left(35^{\circ}-57^{\circ} \mathrm{N} ; 10^{\circ} \mathrm{W}-22^{\circ} \mathrm{E}\right)$, with 8 hybrid-sigma vertical layers extending to $500 \mathrm{hPa}$ can be omitted. Meteorological input is provided by PSU/NCAR MM5 model (Dudhia, 1993) simulations on a Mercator grid with an approximate $30 \mathrm{~km} \times 30 \mathrm{~km}\left(\right.$ at $\left.50^{\circ} \mathrm{N}\right)$ horizontal resolution and 32 vertical sigma layers extending up to $100 \mathrm{hPa}$. The model is forced by the ECMWF ERA-40 reanalysis (before 1 September 2002) or operational ECMWF analyses (afterwards) taken at $1.125^{\circ} \times 1.125^{\circ}$ and using the grid nudging (grid FDDA) option implemented within MM5. MM5 simulations are actually carried out by pieces of 5 days and $6 \mathrm{~h}$, starting at $18 \mathrm{~h} \mathrm{UT}$ and removing the first $6 \mathrm{~h}$ (spin-up period) for the CHIMERE forcing.

Anthropogenic emission data used are based on the socalled "expert" annual data of the EMEP emission inventory (Vestreng et al., 2005) for the year 2002. Annual totals are disaggregated using monthly, daily and hourly factors (Friedrich, 1997) and a speciation of non-methane volatile organic compounds (NMVOC) (Passant et al., 2002). VOC emissions are aggregated into 11 model classes following the mass and reactivity weighting procedure proposed by Middleton et al. (1990). Biogenic emissions for isoprene, terpenes and NO are implemented following the methodology described in Simpson et al. (1999).

CHIMERE uses the MELCHIOR gas-phase chemical mechanism (Lattuati, 1997). From the complete mechanism ( $\sim 80$ compounds, 320 reactions), a reduced mechanism has been derived (Derognat, 2002) according to the concept of chemical operators (Aumont et al., 1996): it includes 44 chemical species and about 120 reactions and is used for this study, but a sensitivity experiment is performed with the extended mechanism.

Chemical boundary conditions for long-lived species are provided by a monthly mean global climatology from LMDz-INCA model (Hauglustaine et al., 2004). The numerical method for the temporal solution of the stiff system of partial differential equations is adapted from the second-order TWOSTEP algorithm originally proposed by Verwer (1994).

The CHIMERE model has been extensively compared to observations. The version used in this study has been thoroughly evaluated in Vautard et al. (2006). In the present study, daily ozone maxima from CHIMERE simulations have been compared to observations from rural EMEP sites: for summers 2001 and 2002 and for surface ozone, the model bias is below $2 \mathrm{ppb}$, RMSE (root mean square error) is $8.5 \mathrm{ppb}$ for both years, correlation is 0.82 and 0.78 respectively. These results are consistent with an evaluation study of the same CHIMERE model version, but using NCEP/MM5 meteorology, as part of the PREV'AIR air quality forecast system (Honoré et al., 2008). In this latter study, for summer 2006, bias for daily ozone maxima with rural AIRBASE sites was on the average below $+1 \mathrm{ppb}$, RMSE $9 \mathrm{ppb}$ and correlation 0.83. In addition, Vautard et al. (2005) showed for a similar model set-up (but with increased vertical resolution), that also AOT60 thresholds were simulated without significant bias for the heat wave case in August 2003.

These model evaluations are considered as very satisfying. However, in order to evaluate the model ability to correctly simulate the ozone-VOC-NO ${ }_{\mathrm{x}}$ relationships, additional continental scale evaluations of simulated various precursors or chemical regime indicator species would be helpful (for example $\mathrm{O}_{3} / \mathrm{NO}_{\mathrm{z}}, \mathrm{H}_{2} \mathrm{O}_{2} / \mathrm{HNO}_{3}$ ratios; Sillman, 1995 , see more detail also in Sect. 3.2). Due to the lack of experimental data, such comparisons are scarce and restricted to the regional scale (see for example the Sillman et al., 2003, study for a comparison of $\mathrm{O}_{3} / \mathrm{NO}_{\mathrm{z}}$ ratios over the Paris region). At European scale, comparison between satellite (from the GOME instrument) and model derived tropospheric $\mathrm{NO}_{2}$ columns showed an average bias of $-10 \%$ and a normalised RMSE of $30 \%$ (for columns temporally averaged over the whole summer season) (Konovalov et al., 2005). Indeed, the tropospheric $\mathrm{NO}_{2}$ column variability is strongly linked to that of boundary layer $\mathrm{NO}_{2}$ concentrations. For VOC species, satellite derived formaldehyde columns have been used for comparison with CHIMERE simulations (Dufour et al., 2009). Formaldehyde is an oxidation product of many VOC species, but its summer column variability over Europe is mostly constrained by that of biogenic VOC emissions. The normalised RMSE for differences between observed and simulated columns (summer 2003 averages) is about 25\%. These comparisons with precursor species are satisfactory, but do not guarantee that the models $\mathrm{O}_{3}-\mathrm{NO}_{\mathrm{x}}$-VOC sensitivity is correct. In particular, the uncertainty in anthropogenic VOC concentrations and emissions cannot be assessed from these comparisons. To test the impact of uncertainty in anthropogenic VOC emissions, a dedicated sensitivity experiment will be performed in Sect. 4 .

\subsection{Set-up of the study}

The study is performed over a three summer periods (May to August). Three different years (2001, 2002 and 2003) are chosen to be able to account for interannual variability in the results. Based on surface ozone observations, it can be stated that summers 2001 and 2002 were typical, but summer 2003 was exceptional for the decade from the mid-nineties to 2004. For instance, Konovalov et al. (2008) calculated summer average $90 \%$ percentiles of daily ozone maxima for 36 EMEP sites representative for European rural 
conditions for 9 summers between 1996 and 2004. Summer 2003 ranked in the first position $\left(146 \mu \mathrm{g} / \mathrm{m}^{3}\right)$, summers 2001 and 2002 ranked in the "middle places", in the $4 .\left(132 \mu \mathrm{g} / \mathrm{m}^{3}\right)$ and 5. position $\left(130 \mu \mathrm{g} / \mathrm{m}^{3}\right)$ out of 9 summers. In addition, European surface ozone observations were analysed by the European Environmental Agency (EEA, 2007). SOMO35 values (see explanation above), found from this study, were very similar for all years between 1996 and 2004 (about $6000 \mu \mathrm{g} / \mathrm{m}^{3}$ day), except for 2003 (about $8000 \mu \mathrm{g} / \mathrm{m}^{3}$ day). As a conclusion, summers 2001 and 2002 can be regarded as typical for a period spanning from the mid nineties to the middle of the first decade of this century, while summer 2003 is exceptional. This conclusion is important for the interpretation of the simulated interannual variability (Sect. 3.3).

For each summer, a reference simulation and two simulations with either anthropogenic $\mathrm{NO}_{\mathrm{x}}$ or NMVOC emissions uniformly reduced by $30 \%$ are performed. The chemical regime is then calculated, for each model grid and time step, as the difference in ozone concentrations between the $\mathrm{NO}_{\mathrm{x}}$ emission and the VOC emission reduction scenario:

D_O $\mathrm{O}_{3}=\mathrm{O}_{3}\left(\mathrm{E}_{\mathrm{NO}_{\mathrm{x}}}-30 \%\right)-\mathrm{O}_{3}\left(\mathrm{E}_{\mathrm{VOC}}-30 \%\right)$

In this way, a VOC $\left(\mathrm{NO}_{\mathrm{x}}\right)$ sensitive regime is characterised by positive (negative) values, i.e. as outlined in the Introduction, a VOC $\left(\mathrm{NO}_{\mathrm{x}}\right)$ sensitive regime corresponds to the case where VOC $\left(\mathrm{NO}_{\mathrm{x}}\right)$ emission reductions are more efficient to reduce ozone values. The chemical regime is not only calculated for average ozone concentrations, but for a series of different ozone targets, defined below, and which have been used as indicators for air quality management. The term " $\mathrm{O}_{3}$ " in Eq. (1) can stand for one of these following ozone targets:

- Daily ozone average $\left(\mathrm{O}_{3}^{\text {moy }}\right)$ : the most basic term for indicating ozone concentrations.

- Daily ozone maximum $\left(\mathrm{O}_{3}^{\max }\right)$ : gives more weight to afternoon photochemical ozone build-up.

- Daily $\mathrm{O}_{\mathrm{x}}$ maximum, with $\mathrm{O}_{\mathrm{x}}=\mathrm{O}_{3}+\mathrm{NO}_{2}\left(\mathrm{O}_{\mathrm{x}}^{\max }\right)$; this term normalises out $\mathrm{O}_{3}$ titration by $\mathrm{NO}$.

- AOT40, AOT60 and AOT90 [ppb h]: $\Sigma_{\text {hours }} \max$ $\left[\left(\left[\mathrm{O}_{3}\right]-40,60,90 \mathrm{ppb}\right), 0\right]$; Accumulated ozone above respectively a 40, 60 and $90 \mathrm{ppb}$ threshold, integrated over the three summers; AOT40 is used as an indicator for ozone impact on vegetation, AOT60 as an indicator for ozone impact on human health; AOT90 indicates exceedance of the air quality information threshold of $180 \mu \mathrm{g} / \mathrm{m}^{3}$ or $90 \mathrm{ppb}$.

- SOMO35 [ppbd] : $\Sigma_{\text {days }} \max$ [(daily maximum $8 \mathrm{~h}$ ozone mean - $35 \mathrm{ppb}$ ), 0] this indicator (Amann et al., 2005) for the ozone health impact corresponds to the accumulation of the highest $8 \mathrm{~h}$ ozone mean during each day above a $35 \mathrm{ppb}$ threshold.
Indeed, one of the objectives of the study is to evaluate possible differences in the chemical regimes for these diverse ozone targets.

\section{Results}

Here results of the chemical regime calculations for the $\mathrm{Eu}-$ ropean domain are presented. First, the average chemical regime over Europe is estimated from simulations over three summer periods. Then, the seasonal and interannual dependence will be addressed. For specific regions, the daily variability will be analysed and compared to modelled chemical regime tracers. Last the long term chemical regime variability will be estimated for past $(1980,1990)$ and future $(2010$, 2020) emission scenarios.

\subsection{Average chemical regime}

The reference simulation (Fig. 1a) over three summer (May to August) periods shows largest average daily surface ozone maxima $\left(\mathrm{O}_{3}^{\max }\right)$ over the Po valley and neighbouring areas $\left(\mathrm{O}_{3}^{\max }\right.$ above $\left.70 \mathrm{ppb}\right)$ and over the Mediterranean basin $\left(\mathrm{O}_{3}^{\max }\right.$ above $60 \mathrm{ppb}$ ). Ozone values decrease gradually with distance from the Mediterranean basin, down to 40 ppb over the British Islands. The scenario with a uniform $30 \%$ decrease in anthropogenic $\mathrm{NO}_{\mathrm{x}}$ emissions results in $\mathrm{O}_{3}^{\max }$ reductions between 3 and 5 ppb over the Mediterranean basin and over Italy. These are indicated in Fig. $1 \mathrm{~b}$ as negative values. On the contrary, over North-Western Europe, the $\mathrm{NO}_{\mathrm{x}}$ emission reductions cause an $\mathrm{O}_{3}^{\max }$ increase, most pronounced over the channel region and the Paris agglomeration ( $>3 \mathrm{ppb}$ ). Also the ship tracks between Spain and North Africa show an increase ( $>2 \mathrm{ppb}$ ). A uniform $30 \%$ decrease in anthropogenic VOC emissions results in $\mathrm{O}_{3}^{\max }$ reductions over the whole model domain, especially large ( $>2$ ppb) over big agglomerations like the London area, parts of Benelux, the Rhine Ruhr area, the Paris agglomeration, the Po valley, Genoa, Naples and Barcelona (Fig. 1c). Note that differences between the scenario run and the reference are inverted in Fig. 1c with respect to Fig. 1b, because this allows simply adding Fig. 1b and $\mathrm{c}$ in order to obtain the chemical regime (as the difference between the $\mathrm{NO}_{\mathrm{x}}$ and the VOC emission reduction scenario, following Eq. 1). Negative values in the south-eastern part of the domain and especially over the Mediterranean basin $(<-2 \mathrm{ppb})$ denote a $\mathrm{NO}_{\mathrm{x}}$ sensitive chemical regime (Fig. 1d). On the contrary, strongly positive values over North-Western Europe (up to $7 \mathrm{ppb}$ over the Channel region) indicate a VOC sensitive regime. For this region, both the negative response to $\mathrm{NO}_{\mathrm{x}}$ emission and the positive response to VOC emission changes contribute about equally to the resulting regime. The major ship track off the North African coast also shows a VOC sensitive regime. On the contrary, for the Mediterranean basin, $\mathrm{NO}_{\mathrm{x}}$ and $\mathrm{VOC}$ emission reductions are in concurrence in terms of $\mathrm{O}_{3}^{\max }$ reductions, the 


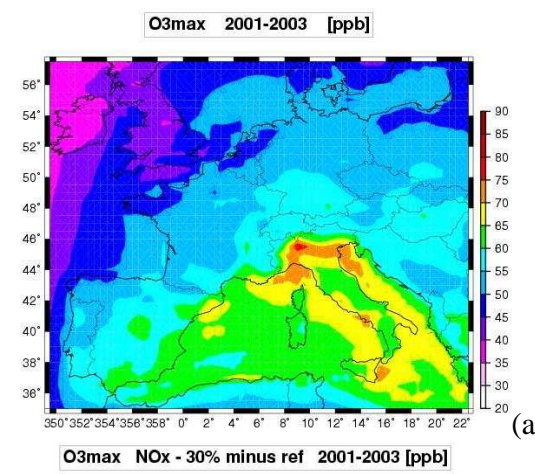

(a)

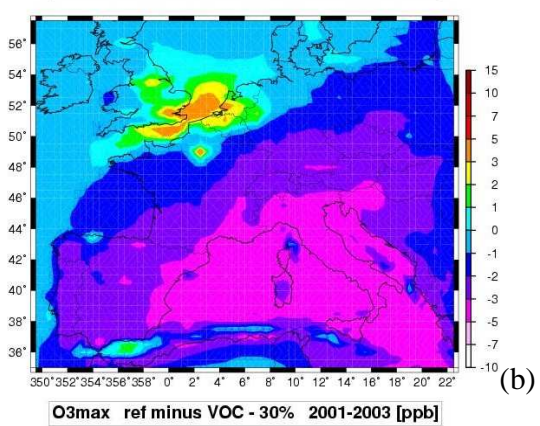

effect of $\mathrm{NO}_{\mathrm{x}}$ emission reductions being larger outside of big agglomerations. Also over most of Germany, both $\mathrm{NO}_{\mathrm{x}}$ and VOC emission reductions are efficient and of equal magnitude resulting in a near neutral chemical regime. The major delimitation line in Northern France between a VOC sensitive chemical regime in North-West Europe and a $\mathrm{NO}_{\mathrm{x}}$ sensitive regime over Southern and Eastern Europe (Fig. 1d) is already apparent in the $\mathrm{NO}_{\mathrm{x}}$ reduction scenario (Fig. 1b).

Next, we investigate how the chemical regime depends on the considered target (always for the average of the three summer periods). To perform this analysis we define three particular regions:

- the region in North-Western Europe with a pronounced VOC sensitive regime $\left(1^{\circ} \mathrm{W}-6^{\circ} \mathrm{E}, 50^{\circ} \mathrm{N}-53^{\circ} \mathrm{N}\right)$,

- the Mediterranean region $\left(6^{\circ} \mathrm{W}-20^{\circ} \mathrm{E}, 38^{\circ} \mathrm{N}-43^{\circ} \mathrm{N}\right)$ with an average $\mathrm{NO}_{\mathrm{x}}$ sensitive chemical regime,

- Northern-Eastern Germany $\left(9^{\circ} \mathrm{E}-14^{\circ} \mathrm{E}, 50^{\circ} \mathrm{N}-54^{\circ} \mathrm{N}\right)$, a transition region between both regimes.

In order to get a quantitative measure for similarities and differences in chemical regimes for different targets, we calculate for each region a series of statistical parameters, relative to the chemical regime average over the three summers 2001-2003 (Table 1): the spatial average of a target over all grid cells in the region, its scatter for individual grid cells, its minimum and maximum values, and the fraction of grid cells with a VOC sensitive regime. The following major results can be drawn from this analysis:

- Over the North-Western Europe region, all targets show a VOC sensitive regime. This is also confirmed by Fig. 2a-j. However, AOT90 shows a less pronounced VOC sensitive character than the other targets: the fraction $f$ of grid cells with a VOC sensitive regime is 0.79 as compared to 0.94 to 1 for the other targets; for AOT90, the mean value characterising the VOC sensitive regime is smaller than its scatter over individual grid cells, while it is always larger for the other targets (Table 1).

- Over the Mediterranean region, the situation is symmetrically opposite to that over North-Western Europe: all targets show a $\mathrm{NO}_{\mathrm{x}}$ sensitive regime for all statistical parameters. Again, the regime is less pronounced for AOT90 $(f=0.18)$, while it is smaller than 0.04 for other targets. This is also confirmed by Fig. $2 \mathrm{a}-\mathrm{j}$, showing a clear $\mathrm{NO}_{\mathrm{x}}$ sensitive regime over most of the Mediterranean region. Note that for AOT90, values are non-zero only for a small part of the region (no or very little 90 ppb threshold exceedences are simulated for a large part of the region).

- Differences in results for different targets are most important for the transition region over North-Eastern Germany and are most obvious in the metrics $f$; it is 0.36 

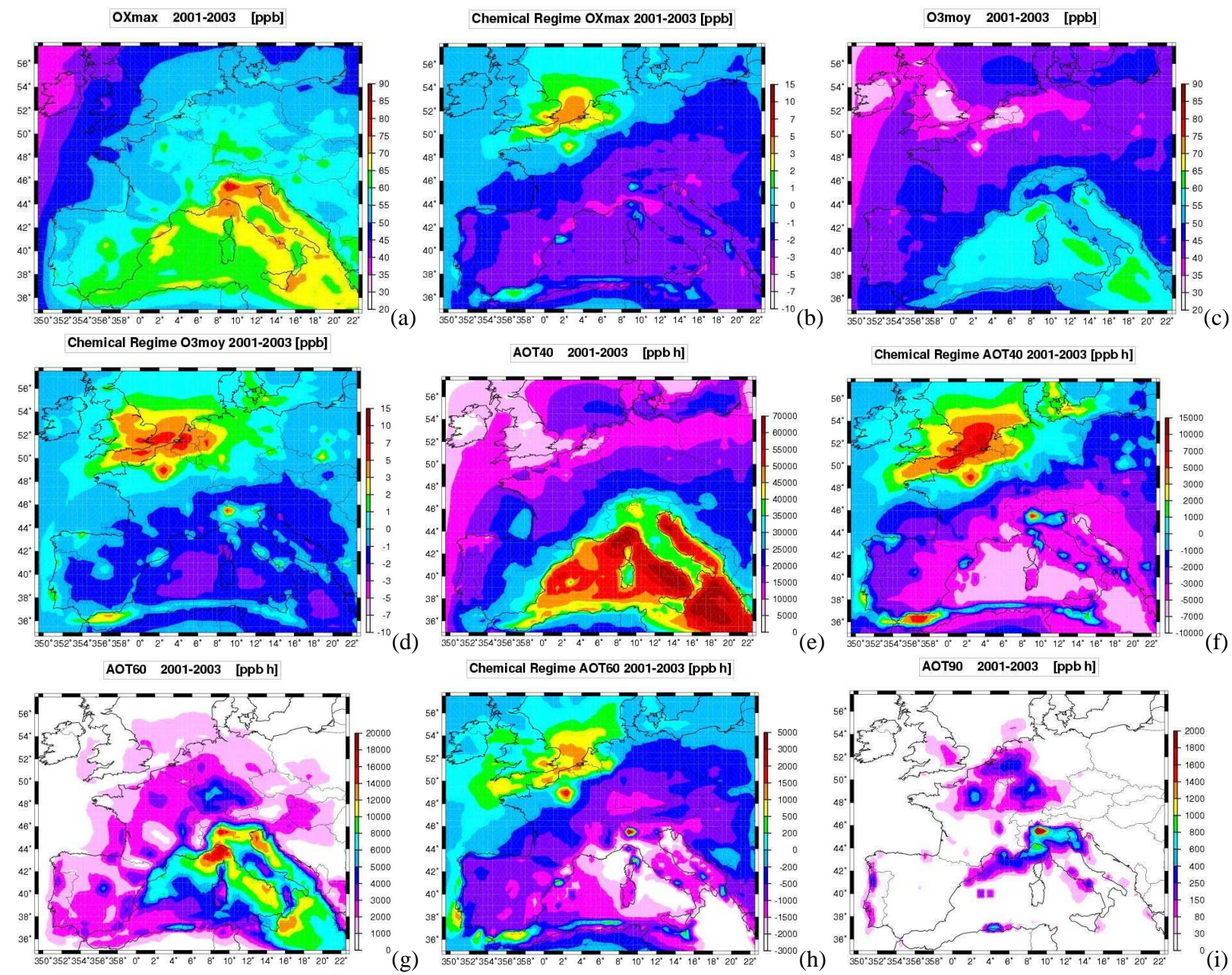

SOMO35 2001-2003 [ppb d]
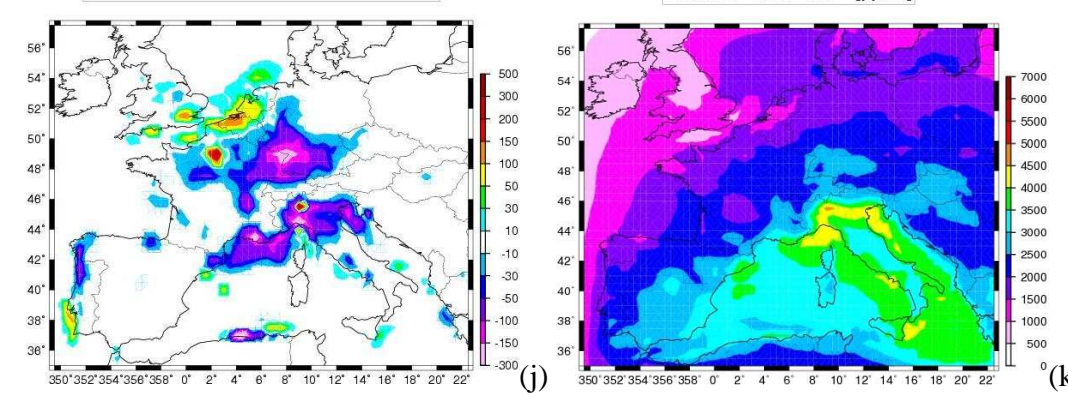

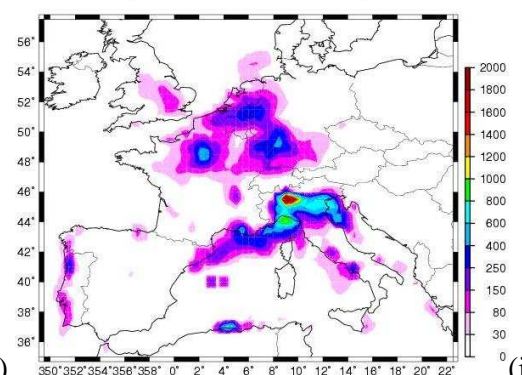

Chemical Regime SOMO35 2001-2003 [ppb d]

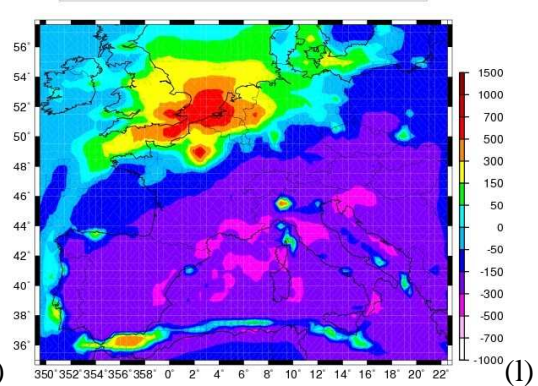

Fig. 2. Reference and chemical regime simulations for different ozone targets (period as in Fig. 1): (a,b) daily $\mathrm{O}_{\mathrm{x}}\left(=\mathrm{O}_{3}+\mathrm{NO}_{2}\right)$ maximum, $(\mathbf{c}, \mathbf{d})$ daily mean ozone, $(\mathbf{e}, \mathbf{f})$ AOT40, (g,h) AOT60, (i,j) AOT90, (k,l) SOMO35; for definition of AOT's and SOMO35 see explanation in the text.

for $\mathrm{O}_{3}^{\max }$ (daily ozone maximum), but zero or near zero for $\mathrm{O}_{\mathrm{x}}^{\max }$ (daily $\mathrm{O}_{\mathrm{x}}=\mathrm{O}_{3}+\mathrm{NO}_{2}$ maximum), AOT60 and AOT90. In conclusion, these latter three targets show a more $\mathrm{NO}_{\mathrm{x}}$ sensitive behaviour than $\mathrm{O}_{3}^{\max }$. This is also confirmed by their negative mean values (indicating a $\mathrm{NO}_{\mathrm{x}}$ sensitive regime). Note however, that for AOT90, only a small part of the North-Eastern Germany region is covered. The fraction $f$ is respectively 0.59 and 0.48 for AOT40 and SOMO35, thus these targets do not show a clearly defined chemical regime, which is again confirmed by a small mean to scatter ratio (below 0.15). Only $\mathrm{O}_{3}^{\text {moy }}$ clearly shows a VOC sensitive chemical regime, with $f$ equal to 0.97 and a positive mean larger than its scatter (Table 1). These differences with respect to targets are also obvious in Fig. 2. The delimitation line between $\mathrm{NO}_{\mathrm{x}}$ and a VOC sensitive chemical regime 
Table 1. Statistical measures for the average chemical regime statistics for summers 2001-2003; sigma, min and max denote the spatial variability of temporal averages, $f>0$ the fraction of grid cells with average VOC sensitive chemical regime; for three regions:

(a) North-Western Europe (NWEU, $\left.1^{\circ} \mathrm{W}-6^{\circ} \mathrm{E}, 50^{\circ} \mathrm{N}-53^{\circ} \mathrm{N}\right)$, (b) Mediterranean (MED, $\left.6^{\circ} \mathrm{W}-20^{\circ} \mathrm{E}, 38^{\circ} \mathrm{N}-43^{\circ} \mathrm{N}\right)$, and (c) North-Eastern Germany (NEG, $\left.9^{\circ} \mathrm{W}-14^{\circ} \mathrm{E}, 50^{\circ} \mathrm{N}-54^{\circ} \mathrm{N}\right)$.

\begin{tabular}{|c|c|c|c|c|c|}
\hline $\begin{array}{l}\text { (a) } \\
\text { NWEU }\end{array}$ & Mean & Sigma & Min & Max & $f>0$ \\
\hline $\mathrm{O}_{3}^{\max }[\mathrm{ppb}]$ & 3.85 & 1.62 & -0.35 & 7.20 & 0.98 \\
\hline $\mathrm{O}_{\mathrm{x}}^{\max }[\mathrm{ppb}]$ & 2.17 & 1.21 & -0.78 & 4.81 & 0.97 \\
\hline $\mathrm{O}_{3}^{\text {moy }}[\mathrm{ppb}]$ & 3.98 & 1.16 & 1.10 & 6.10 & 1 \\
\hline AOT40 [pp h] & 4556 & 1855 & 354 & 7665 & 1 \\
\hline AOT60 [ppb h] & 641 & 446 & -468 & 1571 & 0.94 \\
\hline АОТ90 [ppb h] & 29 & 43 & -28 & 156 & 0.79 \\
\hline SOMO35 [ppb d] & 423 & 170 & -22 & 684 & 0.99 \\
\hline \multicolumn{6}{|l|}{ (b) } \\
\hline MED & Mean & Sigma & Min & Max & $f>0$ \\
\hline $\mathrm{O}_{3}^{\max }[\mathrm{ppb}]$ & -2.17 & 0.58 & -3.56 & 2.20 & 0.01 \\
\hline $\mathrm{O}_{\mathrm{x}}^{\max }[\mathrm{ppb}]$ & -2.37 & 0.45 & -4.01 & 1.95 & 0.01 \\
\hline $\mathrm{O}_{3}^{\text {moy }}[\mathrm{ppb}]$ & -1.55 & 0.57 & -2.23 & 1.96 & 0.04 \\
\hline AOT40 [ppb h] & -4303 & 1566 & -6664 & 1877 & 0.02 \\
\hline AOT60 [ppb h] & -1348 & 665 & -2986 & 958 & 0.01 \\
\hline AOT90 [ppb h] & -12 & 28 & -117 & 75 & 0.18 \\
\hline SOMO35 [ppb d] & -250 & 67 & -370 & 198 & 0.01 \\
\hline \multicolumn{6}{|l|}{ (c) } \\
\hline NEG & Mean & Sigma & Min & Max & $f>0$ \\
\hline $\mathrm{O}_{3}^{\max }[\mathrm{ppb}]$ & -0.21 & 0.59 & -1.59 & 1.19 & 0.36 \\
\hline $\mathrm{O}_{\mathrm{x}}^{\max }[\mathrm{ppb}]$ & -0.85 & 0.52 & -1.85 & 0.22 & 0.03 \\
\hline $\mathrm{O}_{3}^{\text {moy }}[\mathrm{ppb}]$ & +0.99 & 0.52 & -0.13 & 2.23 & 0.97 \\
\hline AOT40 [ppb h] & 98 & 711 & -1787 & 1668 & 0.59 \\
\hline AOT60 [ppb h] & -366 & 176 & -880 & -53 & 0 \\
\hline AOT90 [ppb h] & -8 & 13 & -101 & 0 & 0 \\
\hline SOMO35 [ppb d] & 0 & 67 & -159 & 160 & 0.48 \\
\hline
\end{tabular}

through the North-Eastern Germany region designs the western part as being VOC sensitive, the eastern part as $\mathrm{NO}_{\mathrm{x}}$ sensitive. In line with results from Table 1, this delimitation line is shifted eastwards with respect to $\mathrm{O}_{3}^{\max }$ for $\mathrm{O}_{3}^{\text {moy }}$ and AOT40. Thus a larger part is covered by VOC sensitive regime. The line has a similar position for SOMOS35, and is shifted westwards for $\mathrm{O}_{\mathrm{x}}^{\max }$ and AOT60.

We now briefly discuss reasons for differences in chemical regimes for different targets. The more $\mathrm{NO}_{\mathrm{x}}$ sensitive regimes found for $\mathrm{O}_{\mathrm{x}}^{\max }$ relative to $\mathrm{O}_{3}^{\max }$ result from the fact that ozone titration with fresh $\mathrm{NO}$ emissions adds to a VOC sensitive regime for $\mathrm{O}_{3}$ (through $\mathrm{O}_{3}$ loss with $\mathrm{NO}$ ), but is neutral for $\mathrm{O}_{\mathrm{x}}$ (following the $\mathrm{O}_{\mathrm{x}}$ definition as the sum $\mathrm{O}_{3}+\mathrm{NO}_{2}$ ). This effect is most pronounced in regions with large NO emissions as in North-Western Europe.
For $\mathrm{O}_{3}^{\text {moy }}$, the more VOC sensitive regime with respect to $\mathrm{O}_{3}^{\max }$ is not surprising, because the target includes night time and morning ozone, which is more sensitive to titration by NO. The chemical regime for AOT40 (Fig. 2f) has a similar spatial structure as that for $\mathrm{O}_{3}^{\text {moy }}$. As $\mathrm{O}_{3}^{\text {moy }}$, this target is also sensitive to night time and morning ozone values.

The more $\mathrm{NO}_{\mathrm{x}}$ sensitive chemical regime for AOT60 as compared to $\mathrm{O}_{3}^{\max }$ (especially over North-Eastern Germany) is not easy to explain. It could be that the situations with larger ozone levels collected by this target favour a more $\mathrm{NO}_{\mathrm{x}}$ sensitive regime, due to enhanced radical production through ozone photolysis during ozone rich conditions.

The AOT90 spatial distribution has a rather patchy structure, i.e. for many more rural regions, AOT90 is zero or near zero, because the $90 \mathrm{ppb}$ threshold is not (often) exceeded. The results of a less pronounced VOC sensitive chemical regime over North-Western Germany and of a less pronounced $\mathrm{NO}_{\mathrm{x}}$ sensitive chemical regime the Mediterranean seem contradictory and are again not easy to explain. Clearly, only a small part of events during summers 2001 to 2003 is sampled by this target.

As a conclusion, we point out the similarity in the spatial distribution in the chemical regime for different ozone targets with a predominant VOC chemical regime over NorthWestern Europe and a predominant $\mathrm{NO}_{\mathrm{x}}$ sensitive regime in the Mediterranean region. This is an important result of this study, as it demonstrates the robustness of the chemical regime concept as well as the robustness of its application to Europe. When analysing transition regions as North-Eastern Germany, differences in chemical regimes for different targets also become apparent: for $\mathrm{O}_{3}^{\text {moy }}$ and AOT40, the chemical regime is more VOC sensitive than for $\mathrm{O}_{3}^{\max }$, for $\mathrm{O}_{\mathrm{x}}^{\max }$ and AOT60, it is more $\mathrm{NO}_{\mathrm{x}}$ sensitive.

\subsection{Relation to chemical regime indicators}

In this section, we attempt to relate the average spatial structure of the chemical regime (for the case of $\mathrm{O}_{3}^{\max }$ ) to several explanatory factors, in particular to emission strength and accumulation, and to radical production and loss processes. This analysis is based on specific trace gas concentrations or ratios which have been widely used as so called "chemical regime indicators" in urban and urban plume studies (Milford et al., 1994; Sillman, 1995, and others).

As expected from theory (see Sect. 1), the chemical regime is more VOC sensitive in regions with large $\mathrm{NO}_{\mathrm{x}}$ emissions (Fig. 3a), as especially over North-Western Europe (from Southern England to Western Germany), but also over parts of the Po valley, and the ship tracks in the Mediterranean Sea. $\mathrm{NO}_{\mathrm{y}}$ has been proposed by Milford et al. (1994) as an indicator discriminating chemical regimes, because it is a tracer of $\mathrm{NO}_{\mathrm{x}}$ emissions that an air mass received during its recent history (hours to days). They found that a $\mathrm{NO}_{\mathrm{y}}$ threshold value between 10 and $25 \mathrm{ppb}$ separates the two chemical regimes for different polluted areas in US. Vogel et al. (1999) 


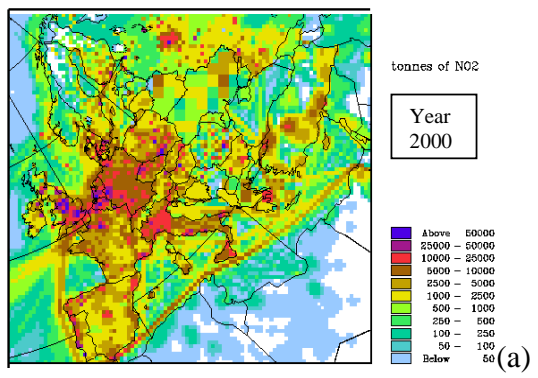

NOY [ppb ] 0-50m May-August 2001

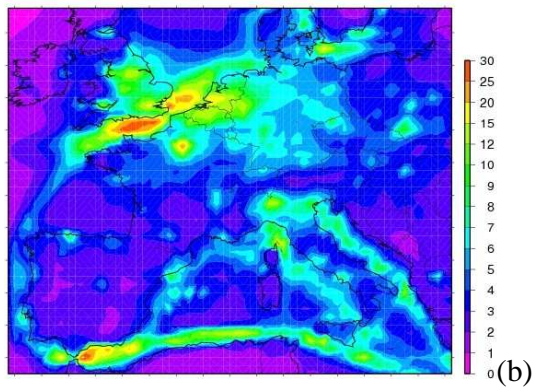

H2O2/ NOz ratio 0-50m May-August 2001

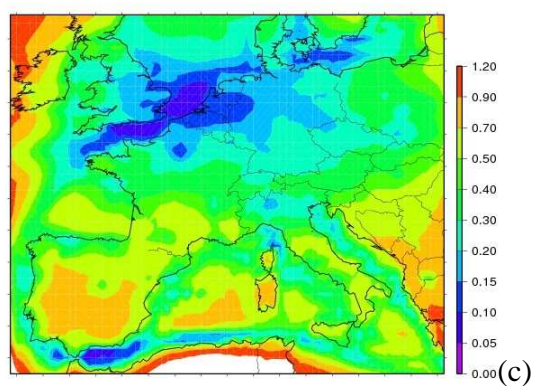

O3 / NOz ratio 0-50m May-August 2001

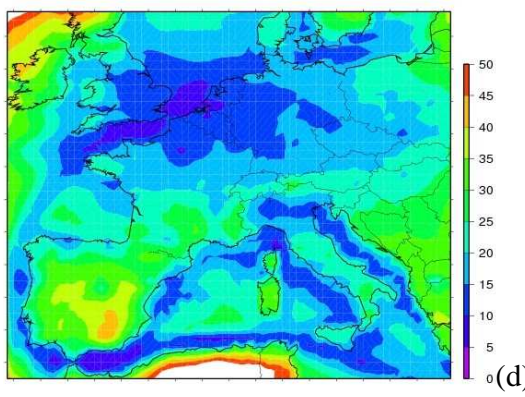

Fig. 3. Maps of annual $\mathrm{NO}_{\mathrm{x}}$ emissions $\left(\mathrm{NO}_{2}\right.$ equivalent) for year 2000 per $50 \times 50 \mathrm{~km}^{2}$ grid cells, from $\operatorname{EMEP}(\mathbf{a})$, chemical regime indicator concentration or ratios (averaged over summer 2001): (b) $\mathrm{NO}_{\mathrm{y}}[\mathrm{ppb}]$, (c) $\mathrm{H}_{2} \mathrm{O}_{2} / \mathrm{NO}_{\mathrm{z}}$ ratio, (d) $\mathrm{O}_{3} / \mathrm{NO}_{\mathrm{z}}$ ratio.

found threshold $\mathrm{NO}_{\mathrm{y}}$ values between 6 and 13 ppb for SouthWestern Germany and discussed their variability with respect to the $\mathrm{VOC} / \mathrm{NO}_{\mathrm{x}}$ emission ratio, meteorological conditions and ozone advection.

In our study, large $\mathrm{NO}_{\mathrm{y}}$ concentrations (Fig. 3b, average over summer 2001) are found in large emissions areas (for example Southern England) or in their lee (i.e. over the North sea), or over ship tracks in the Mediterranean basin, where
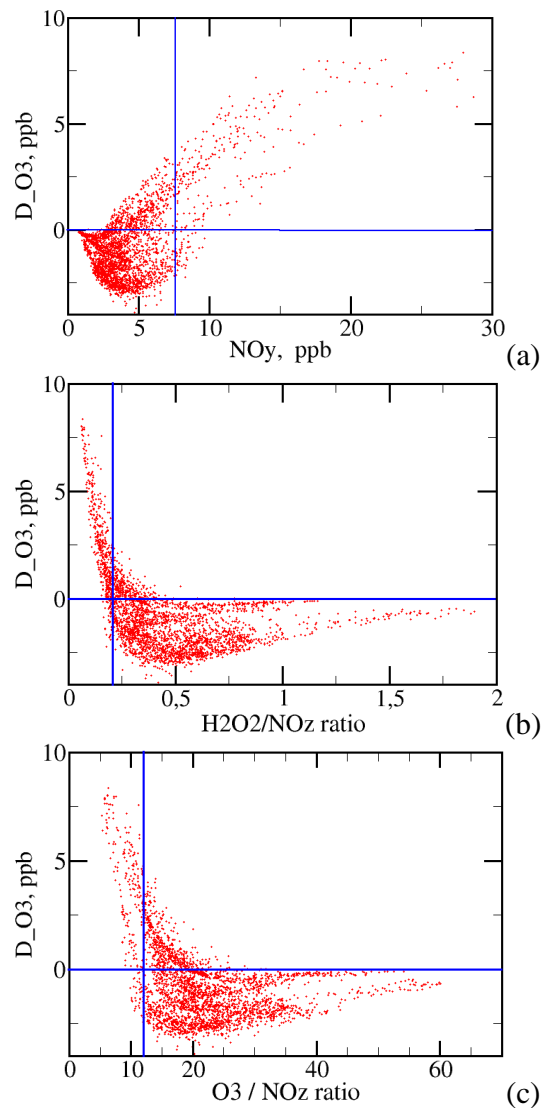

(c)

Fig. 4. Relations between chemical regimes and indicators, averaged over summer (May-August) 2001 at 15:00 UT, as in Table 2. Each point in the scatter plot corresponds to values for individual grid cells.

vertical emission dispersion is low in the model. $\mathrm{NO}_{\mathrm{y}}$ concentrations fairly well correlate with the chemical regimes as depicted in Fig. 1d. The spatial correlation $(R)$ between the chemical regime and $\mathrm{NO}_{\mathrm{y}}$ concentrations, both averaged for summer 2001 at $15 \mathrm{~h}$, is 0.63 , see Table 2 and Fig. $4 \mathrm{a}$. A threshold value of $7.6 \mathrm{ppb}$ can be determined which optimally discriminates about $83 \%$ of the chemical regimes (i.e. $83 \%$ of the grid cells assigned to a particular regime as a function of the indicator really indicate the correct chemical regime, while $17 \%$ indicate the wrong one; for other threshold values, the fraction of correct predictions would be smaller). This threshold value is at the lower end of the range of values given in the literature (between 6 and $25 \mathrm{ppb}$, see the paragraph above), which can be explained by several reasons: (1) the lower $\mathrm{VOC} / \mathrm{NO}_{\mathrm{x}}$ emission ratio over Europe compared to US where biogenic VOC emissions are much larger (e.g. Curci et al., 2009), (2) a larger domain considered in our study making loss of the $\mathrm{NO}_{\mathrm{y}}$ tracer through rapid $\mathrm{HNO}_{3}$ dry deposition more critical (i.e. deposition processes tend to lower the $\mathrm{NO}_{\mathrm{y}}$ indicator value for a given chemical regime, because ozone deposition, the major PBL ozone loss, 
Table 2. Relations between chemical regimes and indicators, averaged over summer (May-August) 2001 at 15:00 UT.

\begin{tabular}{lccc}
\hline Indicator & $\mathrm{H}_{2} \mathrm{O}_{2} / \mathrm{NO}_{\mathrm{z}}$ & $\mathrm{O}_{3} / \mathrm{NO}_{\mathrm{z}}$ & $\mathrm{NO}_{\mathrm{y}}[\mathrm{ppb}]$ \\
\hline $\begin{array}{l}\text { Spatial correlation with } \\
\text { chemical regime }\end{array}$ & $-0.82^{1}$ & $-0.64^{1}$ & 0.63 \\
$\begin{array}{l}\text { Threshold value } \\
\text { (literature values in }\end{array}$ & 0.205 & 12.1 & 7.6 \\
parenthesis) & $(0.23-0.41)$ & $(6-11)$ & $(6-25)$ \\
Discriminative capacity & $89 \%$ & $81 \%$ & $83 \%$ \\
\hline
\end{tabular}

${ }^{1}$ Values indicate correlation coefficients with the negative of inverse of the indicator, in order to obtain a near linear relation with the chemical regime.

is slower than $\mathrm{NO}_{\mathrm{y}}$ deposition) and (3) consideration of average conditions in our study with lower ozone concentrations than in studies focussed on pollution episodes.

Our $\mathrm{NO}_{\mathrm{y}}$ threshold value is larger in the southern part of the domain $(\sim 9 \mathrm{ppb})$ than in its northern part $(\sim 6 \mathrm{ppb})$. This is probably due larger odd hydrogen radical $\left(\mathrm{HO}_{\mathrm{x}}=\mathrm{OH}+\mathrm{HO}_{2}+\Sigma \mathrm{RO}_{2}\right)$ production in the southern part of the domain, due both to larger radiation intensity and larger ozone concentrations. This shifts the chemical regime to more $\mathrm{NO}_{\mathrm{x}}$ sensitive for a given amount of $\mathrm{NO}_{\mathrm{x}}$ emissions and $\mathrm{NO}_{\mathrm{y}}$ concentrations (see discussion below and Kleinman et al., 1997).

Another chemical regime indicator, the $\mathrm{H}_{2} \mathrm{O}_{2} / \mathrm{NO}_{\mathrm{Z}}$ ratio, has proven useful, because it takes into account both the impact of emissions and radical production (Sillman, 1995). It compares the time integrated radical sink through $\mathrm{HO}_{\mathrm{x}}+\mathrm{NO}_{\mathrm{x}}$ reactions, yielding $\mathrm{NO}_{\mathrm{z}}$, to the time integrated radical sink through $\mathrm{HO}_{2}+\mathrm{HO}_{2}$ recombination reactions, yielding $\mathrm{H}_{2} \mathrm{O}_{2}$. The latter corresponds to an excess radical production beyond titration with $\mathrm{NO}_{\mathrm{x}}$ emissions, which favours a locally $\mathrm{NO}_{\mathrm{x}}$ sensitive regime (Kleinman, 1997). Threshold values for this indicator are thought to be less dependent on ambient conditions, which has been verified for different European locations for the similar tracer $\mathrm{H}_{2} \mathrm{O}_{2} / \mathrm{HNO}_{3}$ (Hammer et al., 2002). Figure 3c shows low ratios over North-Western Europe and large ratios over most of the Mediterranean Sea, corresponding to the dominant chemical regimes in Fig. 1d (spatial correlation of -0.82 , see Table 2 and Fig. 4b). A threshold value of 0.205 optimally discriminates $89 \%$ of the chemical regimes. This threshold is at the lower end of a range of values given for five US agglomerations (between 0.23 and 0.41; Sillman et al., 1997).

Finally, the chemical regime trace gas ratio $\mathrm{O}_{3} / \mathrm{NO}_{\mathrm{z}}$ separates $81 \%$ of chemical regimes with a threshold value of 12.1 (spatial correlation -0.64) (Figs. 3d and 4c). This is slightly larger than the range of values between 8 and 11 given by Sillman et al. (1997) and larger than the value of 6 to 7 found by Martilli et al. (2002) for a polluted episode in the Po valley (Milano plume). Again, the larger scale considered in our study could imply a loss of $\mathrm{NO}_{\mathrm{z}}$ through $\mathrm{HNO}_{3}$ dry deposition, which would artificially increase the $\mathrm{O}_{3} / \mathrm{NO}_{\mathrm{Z}}$ threshold.

In conclusion, an important result of our study is that trace gas ratios, that have been used to distinguish between chemical regimes on an urban/regional scale during pollution episodes, are still discriminative on a larger, continental scale and for average summer conditions. Threshold values to distinguish chemical regimes found in this work are close to the range of values in the literature. However, it has to be kept in mind that thresholds derived in our work are relative to larger scale features, in particular to differences in chemical regimes in North-Western Europe and the regions around, and that these thresholds can not be directly applied to urban plumes. In the next section, we will use these chemical regime indicators to understand the day to day variability of the chemical regime.

\subsection{Inter-annual, seasonal, and day-to-day variability}

\subsubsection{Interannual variability}

In this section, we examine the temporal variability of chemical regimes, on an inter-annual, seasonal and day to day scale.

Given the differences between the extreme summer 2003, and the typical summers 2001 and 2002 (see Sect. 2.2), it is interesting to analyse if significant differences in chemical regimes can be observed for the target $\mathrm{O}_{3}^{\max }$ :

- over North-Western Europe, and averaged individually for each of the three summers, $97-98 \%$ of the grid cells show a VOC sensitive regime with an average value (over the region) between +3.65 and $+4.06 \mathrm{ppb}$,

- over the Mediterranean, $97-99 \%$ of the grid cells show a $\mathrm{NO}_{\mathrm{x}}$ sensitive regime with an average of -1.92 $-2.40 \mathrm{ppb}$,

- over North-Eastern Germany, differences between summer 2003 and summers 2001/2002 are somewhat larger. For these latter years, 57 and $59 \%$ of grid cells show a $\mathrm{NO}_{\mathrm{x}}$ sensitive regime while it is $73 \%$ for 2003 . The chemical regime averaged for this region is $-0.1 \mathrm{ppb}$ for 2001 and 2002, while it is $-0.4 \mathrm{ppb}$ in 2003 .

As a conclusion, as for the previous analysis with different targets, differences in the chemical regime for the three years are weak for the two regions with pronounced chemical regimes, but are more important for the transition region North-Eastern Germany. Here, summer 2003 is more $\mathrm{NO}_{\mathrm{x}}$ sensitive than summers 2001 and 2002. It is also concluded that the restriction to analysis of a three-summer climatology appears to be justified for this work, because results are very similar, except somewhat larger differences for the transition region for summer 2003. 
Table 3. Statistical measures for the average chemical regime for $\mathrm{O}_{3}^{\max }$ statistics as in Table 1 , but stratified as a function of the month, for the period 2001-2003; (a) North-Western Europe, NWEU, (b) Mediterranean, MED, and (c) North-Eastern Germany, NEG.

\begin{tabular}{lrrrrr}
\hline $\begin{array}{l}\text { (a) } \\
\text { NWEU } \\
\mathrm{O}_{3}^{\text {max }}\end{array}$ & Mean & Sigma & Min & Max & $f>0$ \\
\hline Mai & & & & & \\
June & 4.26 & 1.17 & 0.05 & 5.87 & 1 \\
July & 4.00 & 1.71 & -0.11 & 7.26 & 0.99 \\
August & 3.96 & 2.40 & -1.55 & 9.02 & 0.95 \\
\hline (b) & & & & & \\
MED & Mean & Sigma & Min & Max & $f>0$ \\
O 3 & & & & & \\
\hline Mai & -1.49 & 0.75 & -2.35 & 2.65 & 0.05 \\
June & -2.13 & 0.67 & -3.73 & 3.29 & 0.02 \\
July & -2.21 & 0.52 & -3.89 & 1.76 & 0.01 \\
August & -2.91 & 0.65 & -4.63 & 2.73 & 0.01 \\
\hline (c) & & & & & \\
NEG & Mean & Sigma & Min & Max & $f>0$ \\
O 3 & & & & & \\
\hline Mai & 0.52 & 0.54 & -0.85 & 1.97 & 0.83 \\
June & 0.16 & 0.60 & -1.39 & 1.28 & 0.65 \\
July & 0.24 & 0.73 & -1.41 & 1.84 & 0.61 \\
August & -1.87 & 0.64 & -3.12 & -0.16 & 0 \\
\hline
\end{tabular}

\subsubsection{Month to month variability}

The monthly variability in the chemical regime from May to August are shown in Table 3 and Fig. 5, results for the target $\mathrm{O}_{3}^{\max }$ each month being averaged over years 20012003. The chemical regime distribution is fairly similar for different months. In May, the VOC sensitive regime is spatially slightly more extended over North-Western and Central Europe, with a larger fraction of grid cells showing a VOC sensitive regime over North-Eastern Germany (83\% as compared to $61-65 \%$ in June/July, see Table 3c). However, maximum values in the London/Channel/Benelux region are lower $(<+5 \mathrm{ppb}$, versus $<+7 \mathrm{ppb}$ for the June to August period, see Fig. 5). In August, the delimitation line between chemical regimes is shifted westward with respect to May to July (Fig. 5). As a consequence, over NorthEastern Germany, the regime switches from VOC sensitive during May to July to $\mathrm{NO}_{\mathrm{x}}$ sensitive for August (Table 3c). During August, the $\mathrm{NO}_{\mathrm{x}}$ sensitve regime is also more pronounced over the Mediterranean basin: minimum values are down to $-5 \mathrm{ppb}$ versus down to $-3 \mathrm{ppb}$ for the other months (Fig. 5), average values for the Mediterranean are $-2.9 \mathrm{ppb}$ for August as compared to -2.1 and $-2.2 \mathrm{ppb}$ for June and July (Table $3 \mathrm{~b}$ ). The $\mathrm{NO}_{\mathrm{x}}$ sensitive regimes over the
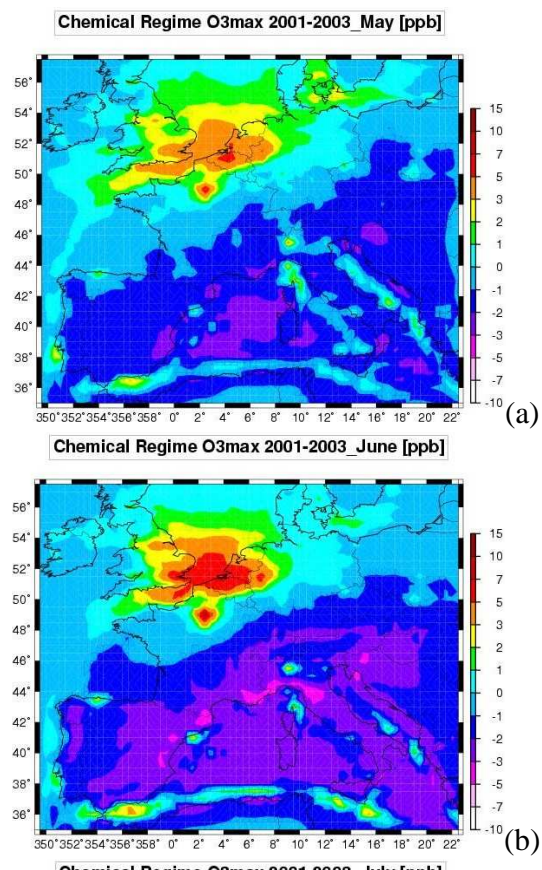

Chemical Regime O3max 2001-2003_July [ppb]
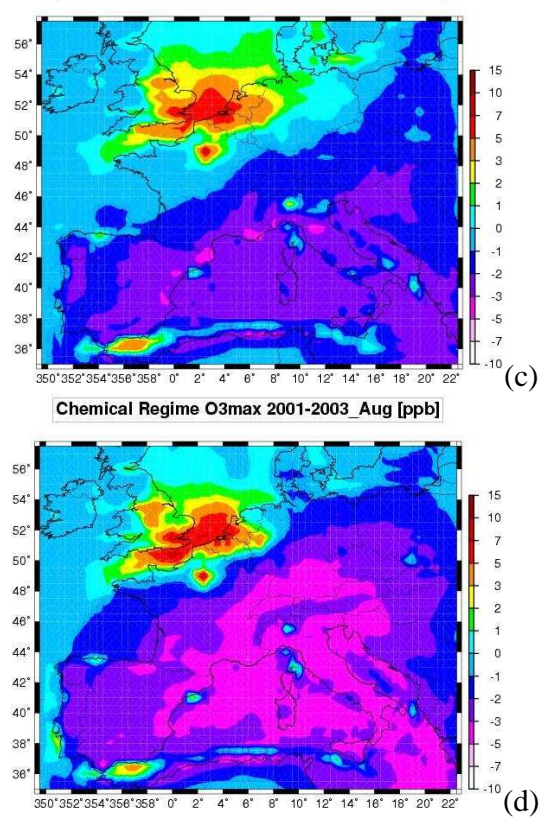

Fig. 5. Average chemical regime (with respect to daily ozone maximum) (a) for May, (b) for June, (c) for July, (d) and for August 2001-2003.

Mediterranean, but also over the southern part of Germany and France, are even more enhanced during August 2003 (Fig. 6), which was characterised during its first half by anticyclonic blocking over Western Europe leading to large regional ozone build-up (e.g. Vautard et al., 2005).

Blocking anticyclonic situations affect chemical regimes in various ways (e.g. Sillman, 1999): stronger emission accumulation a priori favours more VOC sensitive regimes. 


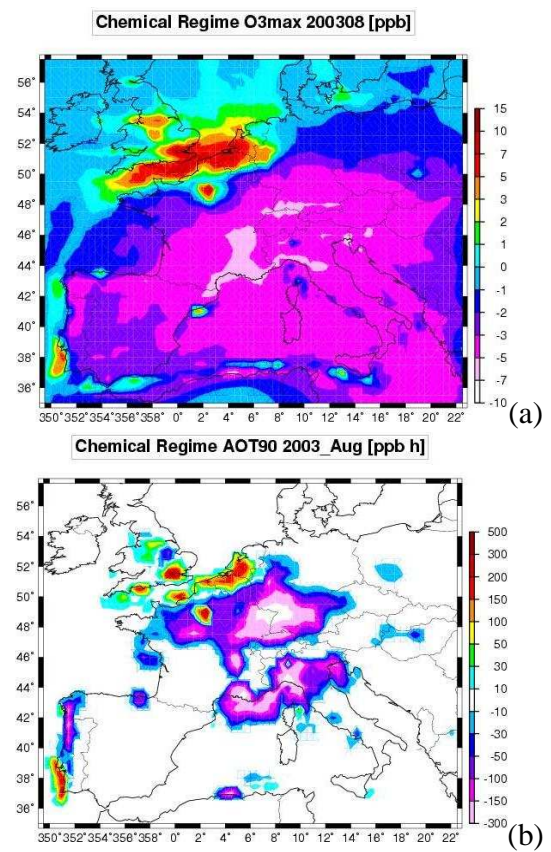

Fig. 6. Chemical regime simulations for August 2003: (a) chemical regime for daily ozone maximum, (b) chemical regime for AOT90.

On the contrary, enhanced emission ageing due to longer residence times over Western Europe, larger biogenic VOC emissions due to enhanced temperature, enhanced radical production due to stronger actinic fluxes and ozone concentrations all favour more $\mathrm{NO}_{\mathrm{x}}$ sensitive regimes. Finally enhanced photochemical ozone build-up implies larger overall sensitivity to local emissions and more pronounced chemical regimes. Unfortunately, shifts in chemical regimes as a function of the meteorological situation cannot be directly predicted from these conflicting arguments.

In conclusion, even if again the pronounced chemical regimes over North-Western Europe and the Mediterranean are robust with respect to the month, the $\mathrm{NO}_{\mathrm{x}}$ sensitive regime is more pronounced in August and especially in August 2003, especially in the transition region in NorthWestern Germany.

\subsubsection{Day to day variability}

We now analyse the day-to-day variability in the chemical regime induced by changes in meteorological conditions, for the $\mathrm{O}_{3}^{\max }$ target and for the three specific regions NorthWestern Europe, Mediterranean and North-Eastern Germany.

Figure 7 shows the daily variability of the chemical regimes for these regions (always at 15:00 UT for summer 2001): always VOC sensitive for North-Western Europe, but with a high variability $\left(+1 \mathrm{ppb}<\mathrm{D}_{-} \mathrm{O}_{3}<+9 \mathrm{ppb}\right)$, always $\mathrm{NO}_{\mathrm{x}}$ sensitive for the Mediterranean $(-3.5 \mathrm{ppb}$ $<\mathrm{D}_{-} \mathrm{O}_{3}<-0.5 \mathrm{ppb}$ ), and variable for North-Eastern Germany $\left(-7 \mathrm{ppb}<\mathrm{D}_{-} \mathrm{O}_{3}<+4 \mathrm{ppb}\right)$. Chemical regime tracers
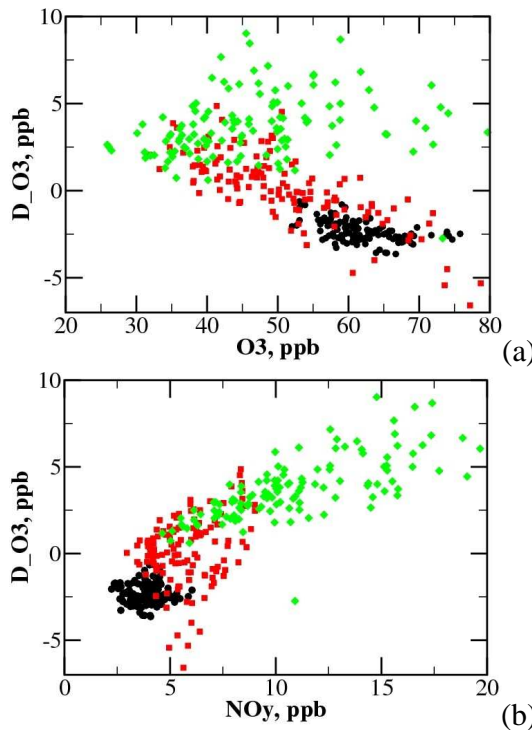

(b)
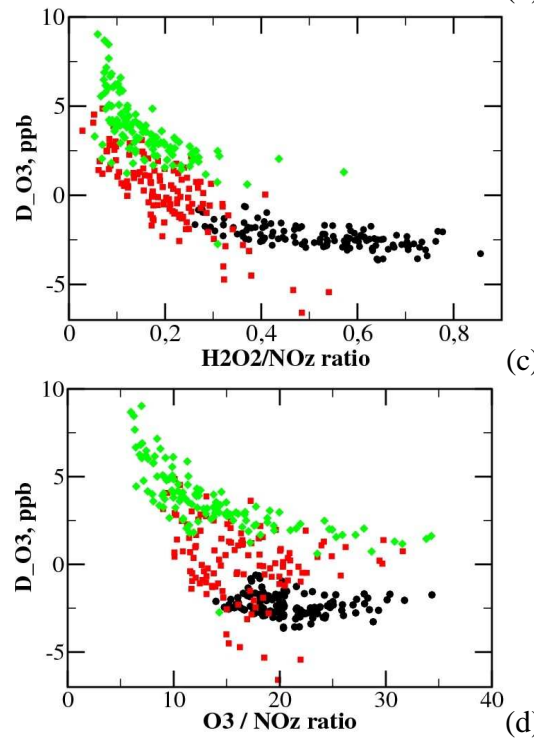

(d)

Fig. 7. Scatter plots of chemical regime at 15:00 UT [ppb] for all days in summer 2001 versus regime indicators : (a) 15:00 UT ozone [ppb], (b) 15:00 UT NO $\left[\mathrm{ppb}\right.$, (c) 15:00 UT $\mathrm{H}_{2} \mathrm{O}_{2} / \mathrm{NO}_{\mathrm{z}} \mathrm{ra}-$ tio, (c) 15:00 UT $\mathrm{O}_{3} / \mathrm{NO}_{\mathrm{Z}}$ ratio. Black circles indicate averages for the Mediterranean area $\left(6^{\circ} \mathrm{W}-20^{\circ} \mathrm{E}, 38^{\circ} \mathrm{N}-43^{\circ} \mathrm{N}\right)$, red squares for North-Eastern Germany $\left(9^{\circ} \mathrm{E}-14^{\circ} \mathrm{E}, 50^{\circ} \mathrm{N}-54^{\circ} \mathrm{N}\right)$, green diamonds for North-Western Europe $\left(1^{\circ} \mathrm{W}-6^{\circ} \mathrm{E}, 50^{\circ} \mathrm{N}-53^{\circ} \mathrm{N}\right)$. Figure $1 \mathrm{~d}$ shows the locations of the three domains.

introduced in Sect. 3.2 are now calculated for each day (at 15:00 UT) and related to the chemical regime. From Fig. $7 b-d$, it can be seen that ranges of values for indicators are distinct for different regions. This is expected from the strong spatial differences in the summer average indicator values presented in Sect. 3.2 corresponding to the different chemical regimes. As for the average chemical regime, the $\mathrm{H}_{2} \mathrm{O}_{2} / \mathrm{NO}_{\mathrm{z}}$ indicator shows more skill than the $\mathrm{O}_{3} / \mathrm{NO}_{\mathrm{z}}$ indicator and the $\mathrm{NO}_{\mathrm{y}}$ indicator for North-Eastern Germany 
and the Mediterranean, as illustrated by larger temporal correlation coefficients (Table 4). This is in agreement with the most physically relevant formulation of the $\mathrm{H}_{2} \mathrm{O}_{2} / \mathrm{NO}_{\mathrm{Z}}$ indicator outlined in Sect. 3.2. It is interesting to note that the more $\mathrm{NO}_{\mathrm{x}}$ sensitive chemical regimes observed over the Mediterranean and North-Eastern Germany (Sect. 3.3) are indeed related to enhanced $\mathrm{H}_{2} \mathrm{O}_{2} / \mathrm{NO}_{\mathrm{z}}$ ratios. For the other chemical regime indicators, strong regional differences in distinctive skill appear: for instance the $\mathrm{O}_{3} / \mathrm{NO}_{z}$ and the $\mathrm{NO}_{\mathrm{y}}$ indicators are valid only for North-Western Europe, but not for North-Eastern Germany and the Mediterranean. North-Western Europe is characterised by strong and fresh $\mathrm{NO}_{\mathrm{x}}$ emissions and thus the $\mathrm{NO}_{\mathrm{y}}$ indicator is more relevant there than over North-Eastern Germany and the Mediterranean where $\mathrm{NO}_{\mathrm{y}}$ concentrations are due to older emissions giving rise to more loss of information by dry deposition.

When studying the chemical regime daily variability, we would like to know if days with high ozone concentrations are related to a particular chemical regime different from average. This is an important issue for air quality management, although it has to be pointed out, that emission reductions applied in this study are constant over the whole European domain (i.e. results do not allow predictions for emission reductions restricted to specific regions). Our results show that for North-Western Europe, the chemical regime is independent of daily ozone maxima, for the Mediterranean it is slightly more $\mathrm{NO}_{\mathrm{x}}$ sensitive for large ozone values and for NorthEastern Germany it is strongly more $\mathrm{NO}_{\mathrm{x}}$ sensitive for large ozone values (Fig. 7a). Thus for large ozone values, relevant for air quality issues, the chemical regime is $\mathrm{NO}_{\mathrm{x}}$ sensitive over North-Eastern Germany. Correspondingly, the chemical regime in this latter region is also slightly $\mathrm{NO}_{\mathrm{x}}$ sensitive with respect to AOT60, a target which gives larger weight on high ozone values (Fig. 2h). Explaining these features is again difficult: enhanced ozone values trigger enhanced radical production by ozone photolysis, and may shift the chemical regime to more $\mathrm{NO}_{\mathrm{x}}$ sensitive. However, days with large ozone values may also be indicative for particular transport patterns and source regions, triggering particular chemical regimes.

As a conclusion, we have shown in this section that indicator species can be used to explain the daily variability of the chemical regime in terms of $\mathrm{NO}_{\mathrm{x}}$ emissions and radical production. Differences in skill of indicators within different regions are apparent. Finally, the chemical regime can also depend on ozone itself. Especially for North-Eastern Germany and to less extent for the Mediterranean region, the regime is more $\mathrm{NO}_{\mathrm{x}}$ sensitive in presence of large ozone levels.

\subsection{Decadal variability with respect to European emission changes}

In this section, we address the impact of estimated past and future emission changes on the chemical regime over
Table 4. Temporal correlation $(R)$ between chemical regimes and indicators at 15:00 UT during summer (May-August) 2001.

\begin{tabular}{lllcr}
\hline Indicator & $\mathrm{H}_{2} \mathrm{O}_{2} / \mathrm{NO}_{\mathrm{z}}$ & $\mathrm{O}_{3} / \mathrm{NO}_{\mathrm{z}}$ & $\mathrm{NO}_{\mathrm{y}}[\mathrm{ppb}]$ & $\mathrm{O}_{3}[\mathrm{ppb}]$ \\
\hline NW Europe & $-0.72^{1}$ & $-0.82^{1}$ & 0.71 & 0.21 \\
NE Germany & -0.80 & -0.17 & 0.30 & -0.75 \\
Mediterranean Basin & -0.65 & -0.15 & 0.04 & -0.52 \\
\hline
\end{tabular}

1 Values indicate correlation coefficients with the negative of inverse of the indicator, in order to obtain a near linear relation with the chemical regime.

Europe. Simulations with summer 2001 meteorology (the summer season that gives results closest to the 2001-2003 average) have been performed for years 1980, 1990, 2010 and 2020 emissions and are compared to the reference simulations with year 2002 emissions. All emissions sets have been taken as expert emissions from the EMEP/Webdab site (http://webdab.emep.int; Vestreng et al., 2005). Emissions for 2010 and 2020 are projections. The same boundary conditions are used for all cases in order to isolate the regional signal. The chemical regimes resulting from these emission data sets are shown in Fig. 8 for the case of $\mathrm{O}_{3}^{\max }$. The most striking feature is the change in magnitude of the VOC sensitive regime over the Southern UK/Channel/Benelux/RhineRuhr region, values decreasing from more than $+15 \mathrm{ppb}$ for 1980 and 1990 to less than +5 ppb for 2010 and 2020. For Germany, a general switch form a VOC sensitive regime in 1980 and 1990 to a $\mathrm{NO}_{\mathrm{x}}$ sensitive regime in 2010 and 2020 can be noted. On the contrary, changes in the intensity in the $\mathrm{NO}_{\mathrm{x}}$ sensitive regime over the Mediterranean basin are only minor. For AOT60 (not shown), the same type of evolution is found, the VOC sensitive regime being much less pronounced in 2010/2020 than in 1980/1990 and the regime shifting from VOC to $\mathrm{NO}_{\mathrm{x}}$ sensitive over Germany. Very low AOT90 is simulated for the years 2010 and 2020, which makes it difficult to use AOT90 as a target for future chemical regime analysis. These changes can be related to the emission changes summarized in Table 5 . For UK, the Benelux, Germany and France, anthropogenic $\mathrm{NO}_{\mathrm{x}}$ and NMVOC emission reductions especially between 1990 and 2010 are very large, reaching about a factor two to three, resulting in the large simulated decrease in VOC sensitivity over that area. Emission changes in the periods 1980 to 1990 and 2010 to 2020 are in general much lower than those between 1990 and 2010, thus the major changes in chemical regimes occur between 1990 and 2010. As a conclusion, there is a clear tendency towards a more $\mathrm{NO}_{\mathrm{x}}$ sensitive chemical regime over Europe over time, consistent with ongoing $\mathrm{NO}_{\mathrm{x}}$ emission reductions. It has to be kept in mind that changing meteorological conditions could also influence ozone concentrations and the chemical regime. Taking these complicated effects into account is beyond the scope of this paper. However, it can be argued that the impact of regional climate changes will take a longer time scale 


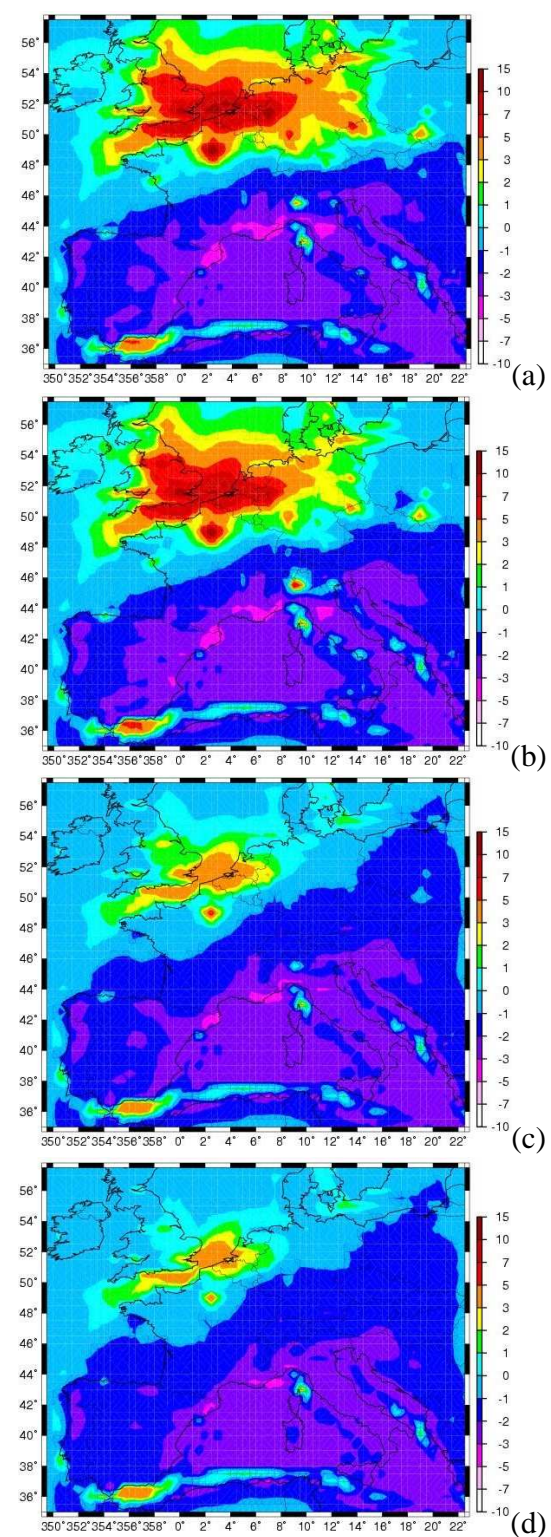

Fig. 8. Chemical regime simulations with respect to daily ozone maximum for summer 2001 meteorology, but for (a) 1980, (b) 1990 emissions, (c) 2010, (d) 2020 emission projections.

to become effective than do emission changes. For instance, summer 2003 showed chemical regime changes comparable or smaller to those due to emissions changes addressed in this section. This type of summer has been proposed as a proxy for regional climate conditions that could occur over Western Europe in the second half of the century (Vautard et al., 2007, and references therein).

\section{Impact of model uncertainty}

In this section, the robustness of simulated chemical regime structure with respect to possible model uncertainty is evaluated. Even if comparison with observations made in previous studies (see Sect. 2) showed rather small model errors in particular for daily ozone maxima, the model sensitivity with respect to emission changes cannot directly be assessed from comparison with observations. Ideally, this problem could be addressed by applying Monte Carlo analysis, which allows taking into account the global model uncertainty. This type of analysis has been performed for the Greater Paris region and it could be shown that the average VOC sensitive regime found over this area was robust with respect to model uncertainties in emissions, meteorological and kinetic data (Beekmann and Derognat, 2003; Deguillaume et al., 2008). However, on a continental scale such an analysis is more difficult to perform, because uncertainties are more difficult to represent with such methods, as perturbations cannot be taken as uniform across the domain (which was the case in the previous local studies). Taking into account a spatial structure for the perturbations would make the number of simulations very large. In the present work, as a first approach the evaluation of model robustness is simply made by performing a small number of specific sensitivity simulations:

1. Anthropogenic VOC emissions are increased by $40 \%$ (as a flat rate for all individual VOC's). Indeed, chemical regimes are sensitive to the $\mathrm{VOC} / \mathrm{NO}_{\mathrm{x}}$ emissions ratio. The value of $40 \%$ (as one sigma confidence level) is a typical value used in former Monte Carlo experiments (e.g. Deguillaume et al., 2007, and references therein) but as a matter of fact, the exact uncertainty in VOC emissions is not known. Modified VOC emission also mimic uncertainties in the photochemical reactivity of the gas phase chemistry scheme.

2. The reduced MELCHIOR gas phase mechanism (40 compounds, $\sim 120$ reactions; Schmidt et al., 2001) was replaced by the extended one ( $\sim 80$ compounds, 320 reactions; Lattuati, 1997). Although this test does not allow testing the full impact of uncertainty in chemical mechanisms, it gives first indications: for example, the operator concept (Aumont et al., 1996), which affects in particular the yield of secondary VOC and thus the $\mathrm{HO}_{\mathrm{x}}$ radical budget, is used in the reduced version of the mechanism, but not in the extended one.

3. Simulations were analysed in the second model layer $(50-200 \mathrm{~m}$ height) instead of the first layer $(0-50 \mathrm{~m}$ height); differences in results indicate the presence of complex vertical structures with low mixing which might be difficult to be resolved by the model. Thus, even if this test cannot assess the overall uncertainty due to vertical mixing, it still allows identifying the regions were this uncertainty is expected to be most critical.

For all these configurations, a reference and two reduction scenario simulation are carried out in order to calculate the 
Table 5. $\mathrm{NO}_{\mathrm{x}}$ and VOC emissions and emission projections for selected countries from http://webdab.emep.int (Vestreng, 2005).

\begin{tabular}{|c|c|c|c|c|c|c|c|c|c|c|}
\hline \multirow[b]{2}{*}{ Year } & \multicolumn{5}{|c|}{$\begin{array}{c}\mathrm{NO}_{\mathrm{x}} \text { emissions } \\
\mathrm{Gg} / \mathrm{yr} \mathrm{NO}_{2} \text { equivalents }\end{array}$} & \multicolumn{5}{|c|}{$\begin{array}{l}\text { NMVOC emissions } \\
\text { Gg/yr }\end{array}$} \\
\hline & 1980 & 1990 & 2002 & 2010 & 2020 & 1980 & 1990 & 2002 & 2010 & 2020 \\
\hline UK & 2580 & 2771 & 1578 & 1113 & 802 & 2100 & 2420 & 1166 & 901 & 863 \\
\hline Benelux ${ }^{1}$ & 1023 & 911 & 671 & 552 & 454 & 853 & 763 & 460 & 409 & 416 \\
\hline Germany & 3333 & 2844 & 1492 & 1174 & 905 & 3223 & 3590 & 1491 & 1140 & 867 \\
\hline France & 2024 & 1897 & 1275 & 1051 & 812 & 2733 & 2499 & 1475 & 1024 & 937 \\
\hline Italy & 1585 & 1918 & 1267 & 980 & 669 & 2032 & 1992 & 1343 & 971 & 732 \\
\hline Spain & 1068 & 1206 & 1420 & 924 & 668 & 1392 & 1591 & 1090 & 832 & 794 \\
\hline
\end{tabular}

${ }^{1}$ Here the sum of emissions for Belgium and the Netherlands is taken.

chemical regime as above. Simulations only cover the month of June 2002 and results are displayed in Fig. 9. For all configurations, the gross structure in the chemical regime with respect to $\mathrm{O}_{3}^{\max }$ and AOT90 (not shown) remains the same as for the standard configuration. For the increased VOC emission case, maximum values within the VOC sensitive regime are in the range of $7-10 \mathrm{ppb}$ instead of 5-7 ppb for the reference case. At first sight this is not consistent with theory, which predicts that regions with enhanced $\mathrm{VOC} / \mathrm{NO}_{\mathrm{x}}$ emission ratio should be more $\mathrm{NO}_{\mathrm{x}}$ sensitive (Kleinman et al., 1997; Sillman, 1999). However, an enhanced initial $\mathrm{VOC} / \mathrm{NO}_{\mathrm{x}}$ ratio in this region triggers enhanced photochemical ozone production (not shown) which actually leads to a more positive value for the chemical regime, which anyway is strongly VOC sensitive. The simulations with the extended and reduced chemical mechanism yield almost identical results (differences in general below half a ppb). The chemical regime in model layer two is very similar to that in the surface layer over continental areas. Indeed, mixing between these two layers in the afternoon and under summer conditions is strong in most cases. However, large differences can be found in coastal areas. VOC sensitive chemical regimes apparent in the surface layer especially near coastal pollution sources disappear in the second model layer (for example over the Adriatic sea, between Genoa and Corsica). Over the ship tracks near the North African coast, the VOC sensitive regime is less pronounced in model layer two than one. This behaviour is due to suppressed vertical mixing over water surfaces, which keeps emissions concentrated near the ground, thus leading to a VOC sensitive regime there. However, the uncertainty of these results with respect to simulated vertical mixing is much stronger than that over continental areas, because only few observational data exist to verify this complex vertical structure. Differences in the chemical regime with respect to AOT90 show the same behaviour than those for $\mathrm{O}_{3}^{\max }$.

As a conclusion to this part, the few sensitivity experiments performed in this study all show a similarity of chemical regimes with the exception of VOC sensitive regimes over the Mediterranean sea (near continental pollution sources or ship tracks). Here, the uncertainty in vertical mixing processes probably prevents from correctly calculating the chemical regime.

\section{Conclusions}

In this work, the robustness and time variability of chemical regimes over Europe during summers 2001 to 2003 has been analysed based on regional scale CTM simulations. A VOC sensitive regime over North-Western Europe (over Southern UK, the Channel region, and parts of the North Sea, the Benelux, Northern France and Western Germany) and a $\mathrm{NO}_{\mathrm{x}}$ sensitive regime over the Mediterranean basin and over Eastern Europe, with exception of ship tracks and several large agglomerations (i.e. Barcelona, Milano), are found. Over Northern Germany, the chemical regime is near neutral. This confirms earlier work by Tarasson et al. (2003) and Derwent (2003). Then, time variability and robustness, with respect to environmental factors and model uncertainty, of this chemical regime structure has been systematically analysed. First, the spatial distribution of chemical regimes is rather unchanged with respect to the ozone target considered: daily maximum ozone or $\mathrm{O}_{\mathrm{x}}$ (sum of $\mathrm{O}_{3}$ and $\mathrm{NO}_{2}$ ), daily mean ozone, AOT40, AOT60, AOT90 and SOMO35. Only over Northern Germany, the chemical regime can shift from either slightly VOC sensitive (for daily mean ozone, AOT40, SOMO35) to slightly $\mathrm{NO}_{\mathrm{x}}$ sensitive (for daily max. $\mathrm{O}_{\mathrm{x}}$, AOT60). Chemical regimes appear also robust over various time scales (year to year, month to month, day to day) for regions with pronounced VOC sensitive (North-West Europe) or $\mathrm{NO}_{\mathrm{x}}$ sensititive (Mediterranean region) chemical regimes. However, for transition regions as North-Eastern Germany, both month-to-month and day-to-day differences are strong. Both VOC and $\mathrm{NO}_{\mathrm{x}}$ sensitive chemical regimes are realised, the latter with an enhanced frequency in August, and when ozone concentrations are larger. During August 2003, when Western Europe was affected by an exceptionally hot and 


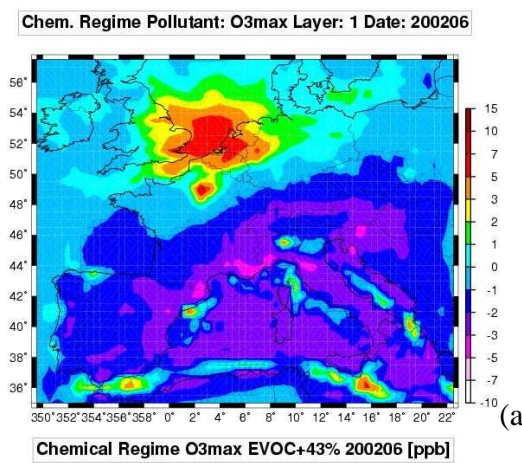

(a)

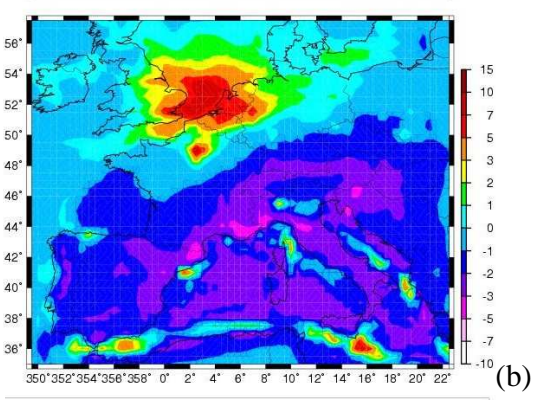

Chemical Regime 03max extended_chemistry 200206 [ppb]

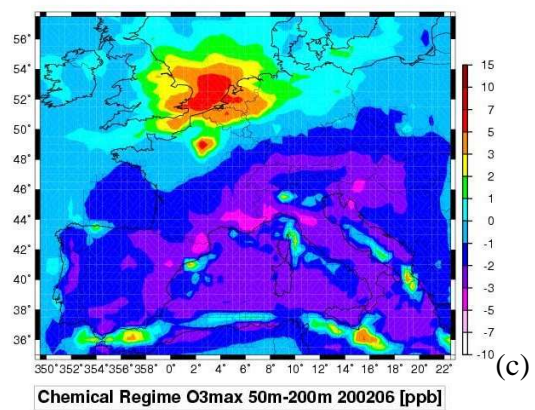

Chemical Regime 03max 50m-200m 200206 [ppb]

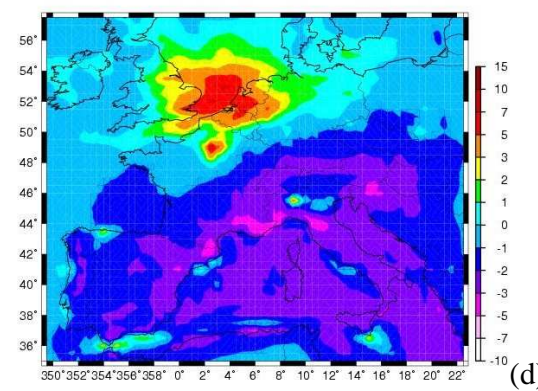

(d)

Fig. 9. Sensitivity of chemical regime simulations with respect model configuration and input data (for June 2002 and with respect to daily ozone maximum): (a) reference, (b) with anthropogenic VOC emissions increased by $40 \%$, (c) with the extended MELCHIOR chemical mechanism instead of the reduced one, (d) results analysed in model layer 2 (50-200 m height) instead of layer 1 (0$50 \mathrm{~m}$ height).

anticyclonic period, the chemical regime structure remained qualititalively unchanged, but differences between VOC and $\mathrm{NO}_{\mathrm{x}}$ sensitive regions were more pronounced.

Emission strength is one of the known key factors determining the occurrence of a chemical regime. We find that the chemical regime strongly responds to past or projected emission changes over Europe between 1980 and 2020. The magnitude of the VOC sensitive regime over North-Western Europe decreases from more than +15 ppb for 1980 and 1990 to less than +5 ppb for 2010 and 2020. For Germany, a general switch form a VOC sensitive regime in 1980 and 1990 to a $\mathrm{NO}_{\mathrm{x}}$ sensitive regime in 2010 and 2020 is simulated, while for the Mediterranean basin changes are minor. As a conclusion, there is a clear decadal tendency towards more $\mathrm{NO}_{\mathrm{x}}$ sensitive regimes over Europe.

The robustness of chemical regimes with respect to model uncertainty (in emissions, chemistry, vertical transport) has also been assessed, without claiming to address overall model uncertainty of the global model or of specific modules. For all configurations the gross structure in the chemical regime remains unchanged. However, uncertainty in vertical transport is expected to affect the chemical regime over water surfaces in the Mediterranean Sea.

The use of indicator species proposed in the literature to predict chemical regimes in particular for pollution episodes has been extended here to a larger spatial and temporal scale. It could be shown that $\mathrm{NO}_{\mathrm{y}}, \mathrm{H}_{2} \mathrm{O}_{2} / \mathrm{NO}_{\mathrm{z}}$ and $\mathrm{O}_{3} / \mathrm{NO}_{\mathrm{z}}$ ratios show distinctive skill for the structure of the summer averaged chemical regime over Europe. They are also correlated with the chemical regime temporal variability, to a different extent for different regions. Use of these indicators allows explaining the spatio-temporal regime variability in terms of variability in emission strength and radical production.

This study aimed at exhibiting regional scale patterns of chemical regimes which are still resolved in a continental scale simulation with a $0.5^{\circ}$ horizontal resolution. But finer urban scale features could not be addressed here, for computer time and memory size reasons it was not possible to perform European wide simulations with high enough resolution (about $5 \mathrm{~km}$; Thunis et al., 2007) to resolve such features. However, progress in computer capacities might allow such type of simulations in future.

Acknowledgements. Catherine Schmechtig at LISA is acknowledged for constant support in setting up a suitable computer environment for performing this work.

Edited by: Jørgen Brandt

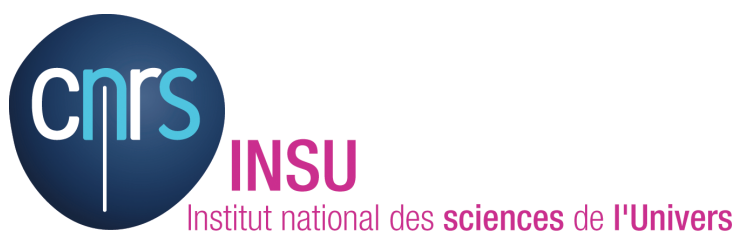

The publication of this article is financed by CNRS-INSU. 


\section{References}

Amann, M., Bertok, I., Cofala, J., Gyarfas, F., Heyes, C., Klimont, Z., Schöpp, W., and Winiwater, W.: Clean Air For Europe (CAFE) Programme final report, Laxenburg, Austria, 2005.

Aumont, B., Jaecker-Voirol, A., Martin, B., and Toupance, G.: Tests of some reduction hypothesis in photochemical mechanisms: Application to air quality modeling in the Paris area, Atmos. Environ., 30, 2061-2077, 1996.

Beekmann, M. and Derognat, C.: Monte Carlo uncertainty analysis of a regional-scale transport chemistry model constrained by measurements from the Atmospheric Pollution Over the Paris Area (ESQUIF) campaign, J. Geophys. Res., 108(D17), 8559, doi:10.1029/2003JD003391, 2003.

Bossioli, E., Tombrou, M., Dandou, A., and Soulakellis, N.: Simulation of the effects of critical factors on ozone formation and accumulation in the greater Athens area, J. Geophys. Res., 112, D02309, doi:10.1029/2006JD007185, 2007.

Coll, I., Pinceloup, S., Perros, P. E., Laverdet, G., and Le Bras, G.: $3 \mathrm{D}$ analysis of high ozone production rates observed during the ESCOMPTE campaign, Atmos. Res., 74, 477-505, 2005.

Curci, G., Beekmann, M., Vautard, R., Smiatek, G., Steinbrecher, R., Theloke, J., and Friedrich, R.: Modelling study of the impact of isoprene and terpene biogenic emissions on European ozone levels, Atmos. Environ., 43, 1444-1455, 2008.

Deguillaume, L., Beekmann, M., and Menut, L.: Bayesian Monte Carlo analysis applied to regional-scale inverse emission modeling for reactive trace gases, J. Geophys. Res., 112, D02307, doi:10.1029/2006JD007518, 2007.

Deguillaume, L., Beekmann, M., and Derognat, C.: Uncertainty evaluation of ozone production and its sensitivity to emission changes over the Ile-de-France region during summer periods, J. Geophys. Res., 113, D02304, doi:10.1029/2007JD009081, 2008.

Derognat, C.: Pollution photo-oxydante à l'échelle urbaine en interaction avec l'échelle régionale, Thèse de doctorat, Université Paris 6, 2002.

Derognat, C., Beekmann, M., Baeumle, M., Martin, D., and Schmidt, H.: Effect of biogenic volatile organic compound emissions on tropospheric chemistry during the Atmospheric Pollution Over the Paris Area (ESQUIF) campaign in the Ile-de-France region, J. Geophys. Res., 108(D17), 8560, doi:10.1029/2001JD001421, 2003.

Derwent, R. G., Jenkin, M. E., Saunders, S. M., Pilling, M. J., Simmonds, P. G., Passant, N. R., Dollard, G. J., Dumitrean, P., and Kent, A.: Photochemical ozone formation in north west Europe and its control, Atmos. Environ, 37, 1983-1991, 2003.

Dufour, G., Wittrock, F., Camredon, M., Beekmann, M., Richter, A., Aumont, B., and Burrows, J. P.: SCIAMACHY formaldehyde observations: constraint for isoprene emission estimates over Europe?, Atmos. Chem. Phys., 9, 1647-1664, doi:10.5194/acp-9-1647-2009, 2009.

Dudhia, J.: A nonhydrostatic version of the Penn State/NCAR mesoscale model: Validation tests and simulation of an Atlantic cyclone and cold front, Mon. Weather Rev., 121, 1493-1513, 1993.

European Environment Agency: Report No 2/2007, Air pollution in Europe 1990-2004, available at: http://www.eea.europa.eu/ publications/eea_report_2007_2, last access: October, 2010.
Friedrich, R.: GENEMIS: Assessment, improvement, temporal and spatial disaggregation of European emission data, in: Tropospheric Modelling and Emission Estimation, part 2, edited by: Ebel, A., Friedrich, R., and Rhode, H., Springer, New York, 181214, 1997.

Gabusi, V. and Volta, M.: Seasonal modelling assessment of ozone sensitivity to precursors in northern Italy, Atmos. Environ, 39, 2795-2804, 2005.

Guttikunda, S. K., Tang, Y., Carmichael, G. R., Kurata, G., Pan, L., Streets, D. G., Woo, J.-H., Thongboonchoo, N., and Fried, A.: Impacts of Asian megacity emissions on regional air quality during spring 2001, J. Geophys. Res., 110, D20301, doi:10.1029/2004JD004921, 2005.

Hammer, M.-U., Vogel, B., and Vogel, H.: Findings on $\mathrm{H}_{2} \mathrm{O}_{2} / \mathrm{HNO}_{3}$ as an indicator of ozone sensitivity in BadenWürttemberg, Berlin-Brandenburg, and the Po valley based on numerical simulations, J. Geophys. Res., 107(D18), 8190, doi:10.1029/2000JD000211, 2002.

Hauglustaine, D. A., Hourdin, F., Walters, S., Jourdain, L., Filiberti, M.-A., Larmarque, J.-F., and Holland, E. A.: Interactive chemistry in the Laboratoire de Météorologie Dynamique general circulation model: description and background tropospheric chemistry evaluation, J. Geophys. Res., 109, D04314, doi:10.1029/2003JD003957, 2004.

Hodzic, A., Vautard, R., Chepfer, H., Goloub, P., Menut, L., Chazette, P., Deuzé, J. L., Apituley, A., and Couvert, P.: Evolution of aerosol optical thickness over Europe during the August 2003 heat wave as seen from CHIMERE model simulations and POLDER data, Atmos. Chem. Phys., 6, 1853-1864, doi:10.5194/acp-6-1853-2006, 2006.

Honoré, C. , Rouïl, L., Vautard, R., Beekmann, M., Bessagnet, B., Dufour, A., Elichegaray, C., Flaud, J.-M., Malherbe, L., Meleux, F., Menut, L., Martin, D., Peuch, A., Peuch, V. H., and Poisson, N.: Predictability of European air quality: The assessment of three years of operational forecasts and analyses by the PREV'AIR system, J. Geophys. Res., 113, D04301, doi:10.1029/2007JD008761, 2008.

Kleinman, L. I., Daum, P. H., Lee, J. H., Lee, Y.-N., Nunnermacker, L. J., Springston, S. R., Newman, L., Weinstein-Lloyd, J., and Sillman, S.: Dependence of ozone production on NO and hydrocarbons in the troposphere, Geophys. Res. Lett., 24, 2299-2302, 1997.

Kleinman, L. I., Daum, P. H., Imre, D. G., Lee, J. H., Lee, Y.N., Nunnermacker, L. J., Springston, S. R., Weinstein-Lloyd, J., and Newman, L.: Ozone production in the New York City urban plume, J. Geophys. Res., 105, 14495-14512, 2000.

Kleinman, L. I., Daum, P. H., Lee, Y.-N., Nunnermacker, L. J., Springston, S. R., Weinstein-Lloyd, J., and Rudolph, J.: A comparative study of ozone production in five U.S. metropolitan areas, J. Geophys. Res., 110, D02301, doi:10.1029/2004JD005096, 2005.

Klemm, O., Stockwell, W. R., Schlager, H., and Krautstrunk, M.: $\mathrm{NO}_{\mathrm{x}}$ or VOC Limitation in East German Ozone Plumes?, J. Atmos. Chem., 35, 1-18, 2000.

Konovalov, I. B., Beekmann, M., Vautard, R., Burrows, J. P., Richter, A., Nüß, H., and Elansky, N.: Comparison and evaluation of modelled and GOME measurement derived tropospheric $\mathrm{NO}_{2}$ columns over Western and Eastern Europe, Atmos. Chem. Phys., 5, 169-190, doi:10.5194/acp-5-169-2005, 2005. 
Konovalov, I. B., Beekmann, M., Richter, A., and Burrows, J. P.: Inverse modelling of the spatial distribution of $\mathrm{NO}_{\mathrm{x}}$ emissions on a continental scale using satellite data, Atmos. Chem. Phys., 6, 1747-1770, doi:10.5194/acp-6-1747-2006, 2006.

Konovalov, I. B., Beekmann, M., Burrows, J. P., and Richter, A.: Satellite measurement based estimates of decadal changes in $\mathrm{Eu}-$ ropean nitrogen oxides emissions, Atmos. Chem. Phys., 8, 2623 2641, doi:10.5194/acp-8-2623-2008, 2008.

Lattuati, M.: Contribution à l'étude du bilan de l'ozone troposphérique à l'interface de l'Europe et de l'Atlantique Nord: Modélisation lagrangienne et mesures en altitude, Ph.D. thesis, Univ. Pierre et Marie Curie, Paris, France, 1997.

Lei, W., de Foy, B., Zavala, M., Volkamer, R., and Molina, L. T.: Characterizing ozone production in the Mexico City Metropolitan Area: a case study using a chemical transport model, Atmos. Chem. Phys., 7, 1347-1366, doi:10.5194/acp-7-1347-2007, 2007.

Liang, J., Horowitz, L. W., Jacob, D. J., Wang, Y., Fiore, A. M., Logan, J. A., Gardner, G. M., and Munger, J. W.: Seasonal budgets of reactive nitrogen species and ozone over the United States, and export fluxes to the global atmosphere, J. Geophys. Res., 103(D11), 13435-13450, 1998.

Martilli, A., Neftel, A., Favaro, G., Kirchner, F., Sillman, S., and Clappier, A.: Simulation of the ozone formation in the northern part of the Po Valley, J. Geophys. Res., 107(D22), 8195, doi:10.1029/2001JD000534, 2002.

Martin, R. V., Fiore, A. M., and Van Donkelaar, A.: Space-based diagnosis of surface ozone sensitivity to anthropogenic emissions, Geophys. Res. Lett., 31, L06120, doi:10.1029/2004GL019416, 2004.

Menut, L.: Adjoint modelling for atmospheric pollution processes sensitivity at regional scale during the ESQUIF IOP2, J. Geophys. Res., 108(D17), 8562, doi:10.1029/2002JD002549, 2003.

Middleton, P., Stockwell, W. R., and Carter, W. P. L.: Aggregation and analysis of volatile organic compound emissions for regional modelling, Atmos. Environ., 24A, 1107-1133, 1990.

Milford, J. B., Gao, D., Sillman, S., Blossey, P., and Russell, A. G.: Total Reactive Nitrogen $\left(\mathrm{NO}_{\mathrm{y}}\right)$ as an Indicator of the Sensitivity of Ozone to Reductions in Hydrocarbon and $\mathrm{NO}_{\mathrm{x}}$ Emissions, $\mathrm{J}$. Geophys. Res., 99, 3533-3542, 1994.

Passant, N. R.: Speciation of UK emissions of NMVOC, AEAT/ENV/0545 report, London, UK, 2002.

Pierce, T., Geron, C., Bender, L., Dennis, R., Tonnesen, G., and Guenther, A.: Influence of increased isoprene emissions on regional ozone modeling, J. Geophys. Res., 103(D19), 2561125629, 1998.

Pison, I., Menut, L., and Bergametti, G.: Inverse modeling of surface $\mathrm{NO}_{\mathrm{x}}$ anthropogenic emission fluxes in the Paris area during the Air Pollution Over Paris Region (ESQUIF) campaign, J. Geophys. Res., 112, D24302, doi:10.1029/2007JD008871, 2007.

Schmidt, H., Derognat, C., Vautard, R., and Beekmann, M.: A comparison of simulated and observed ozone mixing ratios, for the summer of 1998 in Western Europe, Atmos. Environ., 35, 62776297, 2001.

Sillman, S., Al-Wali, K., Marsik, F. J., Nowatski, P., Samson, P. J., Rodgers, M. O., Garland, L. J., Martinez, J. E., Stoneking, C., Imhoff, R. E., Lee, J.-H., Weinstein-Lloyd, J. B., Newman, L., and Aneja, V.: Photochemistry of ozone formation in Atlanta, GA: models and measurements, Atmos. Environ., 29,
3055-3066, 1995.

Sillman, S., He, D., Cardelino, C., and Imhoff, R.: The use of photochemical indicators to evaluate ozone- $\mathrm{NO}_{\mathrm{x}}$-hydrocarbon sensitivity: Case studies from Atlanta, New York and Los Angeles, J. Air Waste Manage., 47, 1030-1040, 1997.

Sillman, S., He, D., Pippin, M., Daum, P. H., Lee, J. H., Kleinman, L., and Weinstein-Loyd, J.: Model correlations for ozone, reactive nitrogen, and peroxides for Nashville in comparison with measurements: Implication for $\mathrm{O}_{3}-\mathrm{NO}_{\mathrm{x}}$-hydrocarbon chemistry, J. Geophys. Res., 103, 22629-22644, 1998.

Sillman, S.: The relation between ozone, $\mathrm{NO}_{\mathrm{x}}$ and hydrocarbons in urban and polluted rural environments, Atmos. Environ., 33, 1821-1845, 1999.

Sillman, S., Vautard, R., Menut, L., and Kley, D.: $\mathrm{O}_{3}-\mathrm{NO}_{\mathrm{x}}-$ VOC sensitivity indicators in Paris: results from models and ESQUIF measurements, J. Geophys. Res., 108(D17), 8563, doi:10.1029/2002JD001561, 2003.

Simpson, D., Olendrzynski, K., Semb, A., Storen, E., and Unger, S.: Photochemical oxidant modelling in Europe: multi-annual modelling and source-receptor relationships, EMEP MSC-W Report 3/1997, 1997.

Simpson, D., Winiwarter, W., Börjesson, G., Cinderby, S., Ferreiro, A., Guenther, A., Hewitt, C. N., Janson, R., Khalil, M. A. K., Owen, S., Pierce, T. E., Puxbaum, H., Shearer, M., Skiba, U., Steinbrecher, R., Tarrasón, L., and Öquist, M. G.: Inventorying emissions from nature in Europe, J. Geophys. Res., 104(D7), 8113-8152, 1999.

Spirig, C., Neftel, A., Kleinman, L. I., and Hjorth, J.: $\mathrm{NO}_{\mathrm{x}}$ versus VOC limitation of $\mathrm{O}_{3}$ production in the Po valley, local and integrated view based on observations, J. Geophys. Res., 107(D22), 8191, doi:10.1029/2001JD000561, 2002.

Tarasson, L., Jonson, J. E., Fagerli, H., Benedictow, A., Wind, P., Simpson, D., and Klein, H.: EMEP Status Report 1/03 Part III, Transboundary acidification and eutrophication and ground level ozone in Europe: Source-Receptor relationships, EMEP/MSCW Report 2003, 2003.

Van Loon, M., Vautard, R., Schaap, M., Bergström, R., Bessagnet, B., Brandt, J., Builtjes, P. J. H., Christensen, J. H., Cuvelier, K., Graf, A., Jonson, J. E., Krol, M., Langner, J., Roberts, P., Rouil, L., Stern, R., Tarrasón, L., Thunis, P., Vignati, E., White, L., and Wind, P.: Evaluation of long-term ozone simulations from seven regional air quality models and their ensemble average, Atmos. Environ., 41, 2083-2097, 2007.

Thunis, P., Rouil, L., Cuvelier, C., Stern, R., Kerschbaumer, A., Bessagnet, B., Schaap, M., Builtjes, P., Tarrason, L., Douros, J., Moussiopoulos, N., Pirovano, G., and Bedogni, M.: Analysis of model responses to emission-reduction scenarios within the CityDelta project, Atmos. Environ., 41, 208-220, 2007.

Vautard, R., Martin, D., Beekmann, M., Drobinski, P., Friedrich, R., Jaubertie, A., Kley, D., Lattuati, M., Moral, P., Neininger, B., and Theloke, J.: Paris emission inventory diagnostics from ESQUIF airborne measurements and a chemistry transport model, J. Geophys. Res., 108(D17), 8564, doi:10.1029/2002JD002797, 2003.

Vautard, R., Honore, C., Beekmann, M., and Rouil, L.: Simulation of ozone during the August 2003 heat wave and emission control scenarios, Atmos. Environ., 39, 2957-2967, 2005. 
Vautard, R., Szopa, S., Beekmann, M., Menut, L., Hauglustaine, D. A., Rouil, L., and Roemer, M.: Are decadal anthropogenic emission reductions in Europe consistent with surface ozone observations?, Geophys. Res. Lett., 33, L13810, doi:10.1029/2006GL026080, 2006.

Vautard, R., Beekmann, M., Desplats, J., Hodzic, A., and Morel, S.: Air quality in Europe during the summer of 2003: a prototype of air quality in a warmer climate, CR Geosci., 339, 747-763, 2007.

Verwer, J. G.: Gauss-seidel iteration for stiff ODEs from chemical kinetics, SIAM J. Sci. Comput., 15, 1243-1250, 1994.
Vestreng, V., Breivik, K., Adams, M., Wagener, A., Goodwin, J., Rozovskkaya, O., and Pacyna, J. M.: Inventory Review 2005, Emission Data reported to LRTAP Convention and NEC Directive, Initial review of HMs and POPs, Technical report MSCW 1/2005, ISSN 0804-2446, 2005.

Vogel, B., Riemer, N., Vogel, H., and Fiedler, F.: Findings on $\mathrm{NO}_{\mathrm{y}}$ as an indicator for ozone sensitivity based on different numerical simulations, J. Geophys. Res., 104, 3605-3620, 1999. 